Research Article

\title{
Numerical Simulation of Surface Subsidence and Backfill Material Movement Induced by Underground Mining
}

\author{
Xibing Li $(\mathbb{D}$, Dongyi Wang, Chongjin Li $(\mathbb{D}$, and Zhixiang Liu \\ School of Resources and Safety Engineering, Central South University, Changsha, Hunan 410083, China \\ Correspondence should be addressed to Chongjin Li; chongjin.li@csu.edu.cn
}

Received 17 January 2019; Accepted 7 April 2019; Published 17 June 2019

Academic Editor: Chun-Qing Li

Copyright (c) 2019 Xibing Li et al. This is an open access article distributed under the Creative Commons Attribution License, which permits unrestricted use, distribution, and reproduction in any medium, provided the original work is properly cited.

\begin{abstract}
Surface subsidence induced by underground mining is one of the challenging problems in mining engineering, which can destroy ground surface buildings and cause huge economic losses to the mine. In this study, a two-dimensional numerical model, established by the discrete element method code PFC2D, was adopted to investigate the mechanical mechanism of surface subsidence and backfill material movement induced by underground mining in the Hongling lead-zinc mine. In the first simulation case, the ore body was excavated from the ground surface to the mining level $705 \mathrm{~m}$ by the sublevel caving mining method, and the stress evolution during the mining process was analyzed to reveal the mechanical mechanism of surface subsidence. In the second and third simulation cases, the mined-out areas above $905 \mathrm{~m}$ were backfilled by the noncemented tailings and an insulating pillar was reserved beneath the backfill material, and then the deep ore body was excavated by two different mining methods to study the movement law of the backfill material and rock strata induced by underground mining. The numerical simulation results show that when the sublevel caving mining method is adopted, underground mining can induce toppling failures in the hanging wall and lead to a large collapse pit in the ground surface. After the toppling failures in the hanging wall, the collapsed waste rock in the mined-out area can provide support force for the surrounding rock and restrict the further collapse of the hanging wall. Furthermore, when the cut-and-fill mining method is adopted for the excavation of deep ore body, the insulating pillar can restrict the horizontal displacement of surrounding rock and maintain the stability of the backfill material. The cut-and-fill mining method can efficiently control the surface subsidence and prevent the occurrence of collapse pit in the ground surface and is recommended for the Hongling lead-zinc mine to solve the surface subsidence problem.
\end{abstract}

\section{Introduction}

Over the last decades, the large-scale exploitation of mineral resources from underground brings mankind great economic and social benefits, but it also gives rise to a series of security and environmental issues, a major one being the surface subsidence problem [1-3]. So far, the sublevel caving (SLC) is still one of the popular mining methods due to the advantages of low cost and high efficiency [4]. However, the sublevel caving fills the mined-out area by means of caving surrounding rock, thus inducing significant strata movement and surface subsidence. The surface subsidence induced by underground mining has become a major issue facing the metal mines all over the world, which not only endangers the ground surface infrastructures but also poses a serious threat to the lives and property safety of personnel [5-7]. Therefore, it is significant to figure out the surface subsidence mechanism and propose proper treatment schemes.

Many studies have been carried out by researchers to investigate the surface subsidence mechanism by means of theoretical analysis, physical modeling, field observation, and numerical simulation. In the aspect of theoretical research, Hoek [8] developed a limit equilibrium analysis to predict the progress failure of hanging wall in the Grängesberg Mine, and his analysis was extended by Brown and Ferguson [9] to account for a sloping ground surface and groundwater pressures in the tension crack and on the shear plane. However, there have been only a few theoretical studies due to the complexity of the problem. Moreover, most of theoretical model are based on many simplification; it is therefore hard to precisely predict the surface deformation via theoretical formulas. As for the physical 
modeling, Ren et al. [10] constructed a physical model to simulate the deformation and failure of ground surface and rock mass around the mined-out area, and the digital closerange photogrammetry was used in their model to measure the displacements of surface and wall rock. Dai et al. [11] also used a physical model test to study the surface deformation induced by fully mechanized caving below a thick loess layer. In addition, the physical modeling was utilized by Ghabraie et al. [12] to investigate the surface subsidence mechanism and substrata movement characteristics due to sequential extraction of partially overlapping longwall panels. In general, the physical similar simulation model is constructed by the similar material that can reproduce the similar characteristics of in situ rock mass, and the dimensionless analysis and similarity principle are also used to correlate the physical model results to the real field model. However, the physical model cannot fully reproduce the surface subsidence and rock failure process in real field due to the difficulty of accurately matching the material properties and other artificial uncertainties introduced during the model construction process.

Field observation is so far the most direct and effective method to study the surface deformation and rock strata movement because the field monitoring data can truly reflect the displacement law of the mine surface and provide guidance for mining activities and support design. There are several methods for monitoring the mining-induced subsidence, such as leveling, theodolite, total station, global positioning system (GPS), and extensometer. GPS, as a common ground surface deformation monitoring technique, was used to monitor the ground surface deformation in many metal mines, such as the Kiirunavaara Mine, Jinchuan Nickel Mine, and Chengchao Iron Mine, and the detailed monitoring data were used to analyze the ground surface deformation characteristics and strata movement mechanism induced by underground mining [13-15]. In addition, the microseismic monitoring technique was adopted by Cheng et al. [16] to investigate the strata movement induced by coal mining in the Dongjiahe Coal Mine. The extradeep multiple-point borehole extensometer technique was introduced to the Jinshandian Iron Mine by Xia et al. [17] for the deformation monitoring of ground surface and deep rock masses, and the monitoring results were used to investigate the ground movement mechanism induced by underground mining. However, these field monitoring methods are limited to ground deformation and lack of mechanical mechanism analysis. The stress redistribution and the fracture initiation and propagation induced by underground mining are difficult to obtain from the field monitoring data.

With the development of computer technique, the numerical simulation has gradually become a low-cost and highly efficient auxiliary method of studying the mechanical mechanism of surface subsidence and strata movement induced by underground mining. In recent years, many numerical codes have been developed and applied to investigate the mining-induced surface subsidence and strata movement, including FLAC3D [18], 3DEC [19], RFPA2D [20], ABAQUS [21], DDA [22, 23], UDEC [24, 25], ELFEN
[26-28], and PFC2D [29-32], and these simulation codes can be classified into three categories: (1) continuous medium method, such as FLAC3D, RFPA2D, and ABAQUS; (2) discontinuous medium method, such as UDEC, 3DEC, DDA, and PFC2D; and (3) hybrid method, such as ELFEN. In the continuous medium model, the rock mass is modeled by the continuous elements, and the element cannot detach from each other. It means that it is difficult to model the collapse process of surrounding rock using the continuous medium model. For the discontinuous medium method and hybrid method however, the numerical model is composed of a set of discontinuous elements. These discrete elements bond with each other and can be detached once the bond breaks. Therefore, the discontinuous medium model and hybrid model can model the large deformation and can be used to reproduce the collapse process of surrounding rock induced by underground mining. The discontinuous models, constructed by UDEC, PFC2D, and ELFEN, have been successfully used to model the surface subsidence by many scholars [24, 26-32].

There are several approaches for dealing with the surface subsidence areas, including (1) backfilling the solid wastes such as waste rocks into the subsidence area; (2) turning the tailings into filter cakes to backfill the subsidence area; (3) transforming the subsidence area into tailing ponds; and (4) blasting the rock mass around the subsidence area for backfill material [33-36]. Among these solving approaches, the approaches 1,2 , and 3 can deal with not only the surface subsidence area but also the waste rocks and tailings, thus obtaining both economic and environmental benefits. While the approach 4 backfills the subsidence area by blasting the rock mass around the subsidence area, which will not only result in new surface subsidence but also have a significant influence on the ground surface environment. Therefore, it is inadvisable to use approach 4 to deal with the surface subsidence area. In addition, when the waste rocks and tailings are backfilled into the active subsidence area (i.e., the mining activities are still carried out under the subsidence area), the stress redistribution and rock strata movement induced by underground mining may have influences on the stability of backfill material. The secondary disasters, such as the massive collapse of backfill material and downhole debris blow, may be caused by the mining activities beneath the subsidence area. In this case, an insulating pillar needs to be reserved beneath the subsidence area and a proper mining method should be reselected in order to maintain the stability of the backfill material [37-39]. Therefore, it is necessary to investigate the stability and movement law of backfill material in the subsidence area induced by underground mining so that the proper mining methods can be proposed.

In this study, a two-dimensional numerical model established by PFC2D was implemented to investigate the mechanism of surface subsidence in the Hongling lead-zinc mine induced by underground mining. Using the numerical model, the whole process of surface subsidence and backfill material movement induced by underground mining can be reproduced, and the mechanical mechanism of surface subsidence can be revealed from the perspective of stress 
evolution. Finally, a proper mining scheme was recommended based on the numerical simulation results.

\section{Site Description}

2.1. Ore Body Layout and Mining Situation. The Hongling lead-zinc mine is located in northern China and is a skarn type polymetallic deposit with lead and zinc. The ore vein has a total length of $5.7 \mathrm{~km}$ and a width of $40 \sim 100 \mathrm{~m}$ and exists mainly in $+500 \sim+1110 \mathrm{~m}$. The ore vein strikes NE $55^{\circ} \sim 59^{\circ}$ and dips $65^{\circ} \sim 85^{\circ}$ toward NW, which is divided into five ore sections from east to west. The main industrial ore bodies are located in the third ore section, which are $1350 \mathrm{~m}$ long and $100 \mathrm{~m}$ wide with a dip angle of $80^{\circ}$ toward NW. The main industrial ore bodies include $1 \#, 1-1 \#$, and 2\# ore bodies, as shown in Figure 1(a). The 1-1\# ore body is actually a branch of the $1 \#$ ore body, and both of them coincide in the shallow part. The $1 \#$ ore body is the main ore body, and mainly locates between exploration lines 1 33. The $2 \#$ ore body is mainly located between exploration lines $2 \sim 13$. The ore body between lines 1 13 is divided into $1 \#$ and 2\# ore body by marble, as shown in Figure 1(b), and the rock mass type of hanging wall and footwall is slate.

The Hongling lead-zinc mine was put into production since 1992. The initial mining method was the shallow hole retention method, and the production capacity was $500 \mathrm{t} / \mathrm{d}$. After transformation in 2006, the production capacity reached $1500 \mathrm{t} / \mathrm{d}$. The mining methods were the sublevel open-stoping method when thickness $>5 \mathrm{~m}$ and the shallow hole retention method when thickness $<5 \mathrm{~m}$. In 2010, the mining method was changed to the sublevel caving method in order to improve the production capacity, which is still used today. The schematic diagram of sublevel caving mining method used in the Hongling lead-zinc mine is shown in Figure 2. The sublevel height is $50 \mathrm{~m}$, and a temporary crown pillar with thickness of $10 \sim 15 \mathrm{~m}$ is reserved. The ore block is $50 \mathrm{~m}$ along the strike of ore body, and the width of the ore block is the thickness of the ore body. At present, there are nine mining levels in the mining area, as shown in Figure 3. The ore body above mining level $995 \mathrm{~m}$ has almost been mined out, and a part of surrounding rock mass has collapsed. The majority of ore body in mining levels $955 \mathrm{~m}$ and $905 \mathrm{~m}$ has been mined, leading to the formation of a large number of mined-out areas. The ore body in mining levels $855 \mathrm{~m}$ and $805 \mathrm{~m}$ is currently mined, and the development system is now being built in the mining levels $855 \mathrm{~m}$ and $805 \mathrm{~m}$.

Before 2010, the mining areas were mainly above $955 \mathrm{~m}$, and a large amount of ore body was remained above $955 \mathrm{~m}$ due to irregular mining, resulting in a great deal of waste of mineral resources. Therefore, the mine began to recover the residual ore body above $955 \mathrm{~m}$ since 2011 . However, with the gradual recovery of residual ore body, the mined-out areas were interconnected with each other, resulting in surface subsidence. By the end of December 2017, there were two major subsidence pits in the ground surface, as shown in Figures 4(a) and 4(b). The area of $1 \#$ subsidence pit is approximately $68,400 \mathrm{~m}^{2}$ with a length of $645 \mathrm{~m}$ and an average width of $103 \mathrm{~m}$, and the area of 2\# subsidence pit is approximately $1,200 \mathrm{~m}^{2}$ with a length of $51 \mathrm{~m}$ and an average width of $24 \mathrm{~m}$. In addition, a large number of tensile cracks along the strike direction of ore body appear in ground surface of hanging wall due to underground mining, as shown in Figure 4(c). At present, the subsidence areas are still enlarging due to the continued underground mining, which poses a threat to the safety of underground workers and ground surface buildings such as main road, staff quarters, and shafts. Therefore, it is an urgent issue for the Hongling lead-zinc mine to solve the surface subsidence problem.

2.2. Rock Mass Properties and In Situ Stress. In order to obtain the mechanical properties of surrounding rock masses and ore body, some relatively intact rock blocks were firstly extracted from the Hongling lead-zinc mine and made into standard specimens with a diameter of $50 \mathrm{~mm}$ and a height of $100 \mathrm{~mm}$. Then, the mechanical properties of intact rock were obtained through unconfined uniaxial compression test in the laboratory using the standard specimens, and finally the mechanical properties of rock mass can be obtained according to Hoek-Brown criterion [40], as shown in Table 1.

The measurement results of in situ stress show that the obvious horizontal tectonic stress exists in the mining area. The direction of the maximum horizontal principal stress is $\mathrm{NE} 5^{\circ} \sim 22^{\circ}$, and the direction of the minimum horizontal principal stress is $\mathrm{NW} 68^{\circ} \sim 85^{\circ}$. The final fitting equations of the vertical principal stress $\left(\sigma_{\mathrm{v}}\right)$, maximum horizontal principal stress $\left(\sigma_{\mathrm{Hmax}}\right)$, and minimum horizontal principal stress $\left(\sigma_{\mathrm{Hmin}}\right)$ are presented as follows:

$$
\begin{aligned}
\sigma_{\mathrm{v}} & =0.0279 h, \\
\sigma_{\text {Hmax }} & =0.0256 h+10.202, \\
\sigma_{\text {Hmin }} & =0.0233 h+1.4743 .
\end{aligned}
$$

\section{Modeling Methodology}

3.1. Microscopic Parameter Calibration and Numerical Model Setup. In this study, the two-dimensional particle flow code (PFC2D) was used as a simulation tool to investigate the mechanism of surface subsidence and backfill material movement due to underground mining. The particle flow code is based on the discrete element method (DEM) and uses an assembly of discrete grains or cemented particles to mimic the granular or intact material. In the PFC model, the contact bond model (CBM) and the parallel bond model (PBM) are two basic bond models that can be used to cement the particles to model the intact rock material [41]. The contact bond can only transmit the force, while the parallel bond can transmit both force and moment between particles. The PBM is a more realistic bond model for modeling the rock-like material and has been successfully used in previous studies [42, 43], which was therefore adopted in this study. The maximum tensile and shear stresses acting on the parallel-bond periphery are calculated from beam theory: 


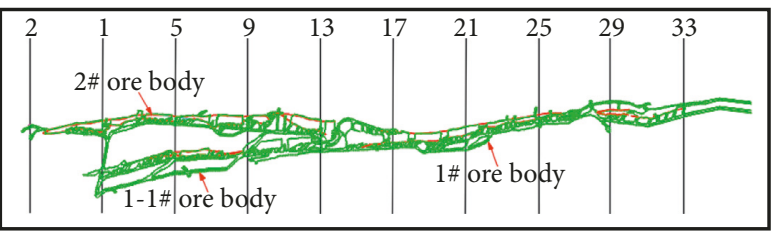

(a)

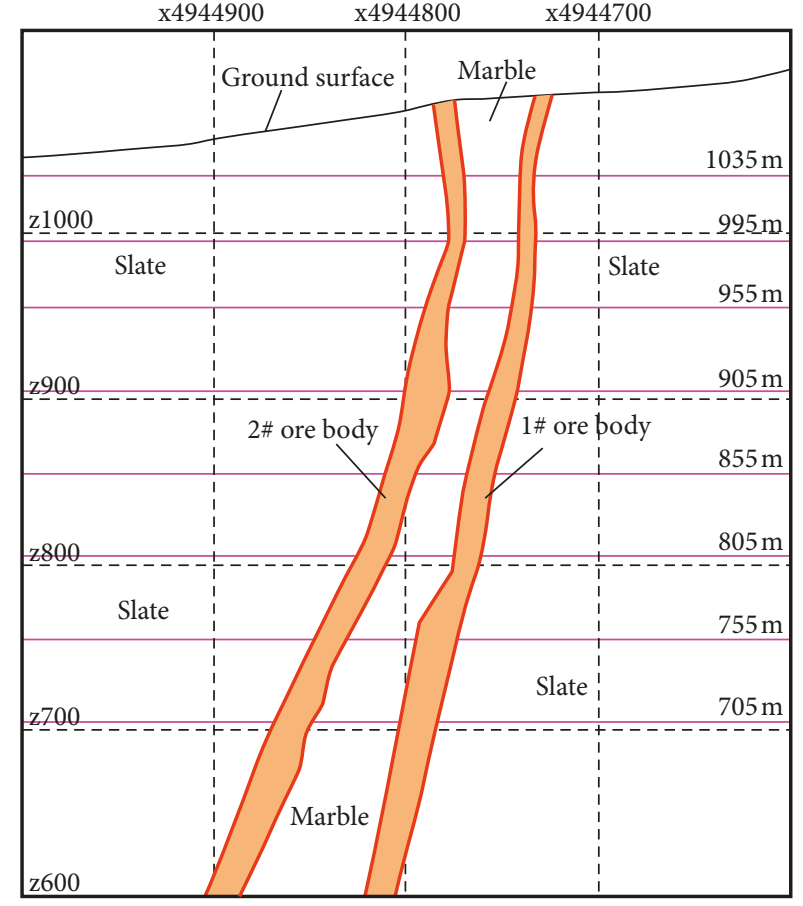

(b)

Figure 1: Ore body layout. (a) Plan view of the ore body. (b) Geological profile of exploration line 5.
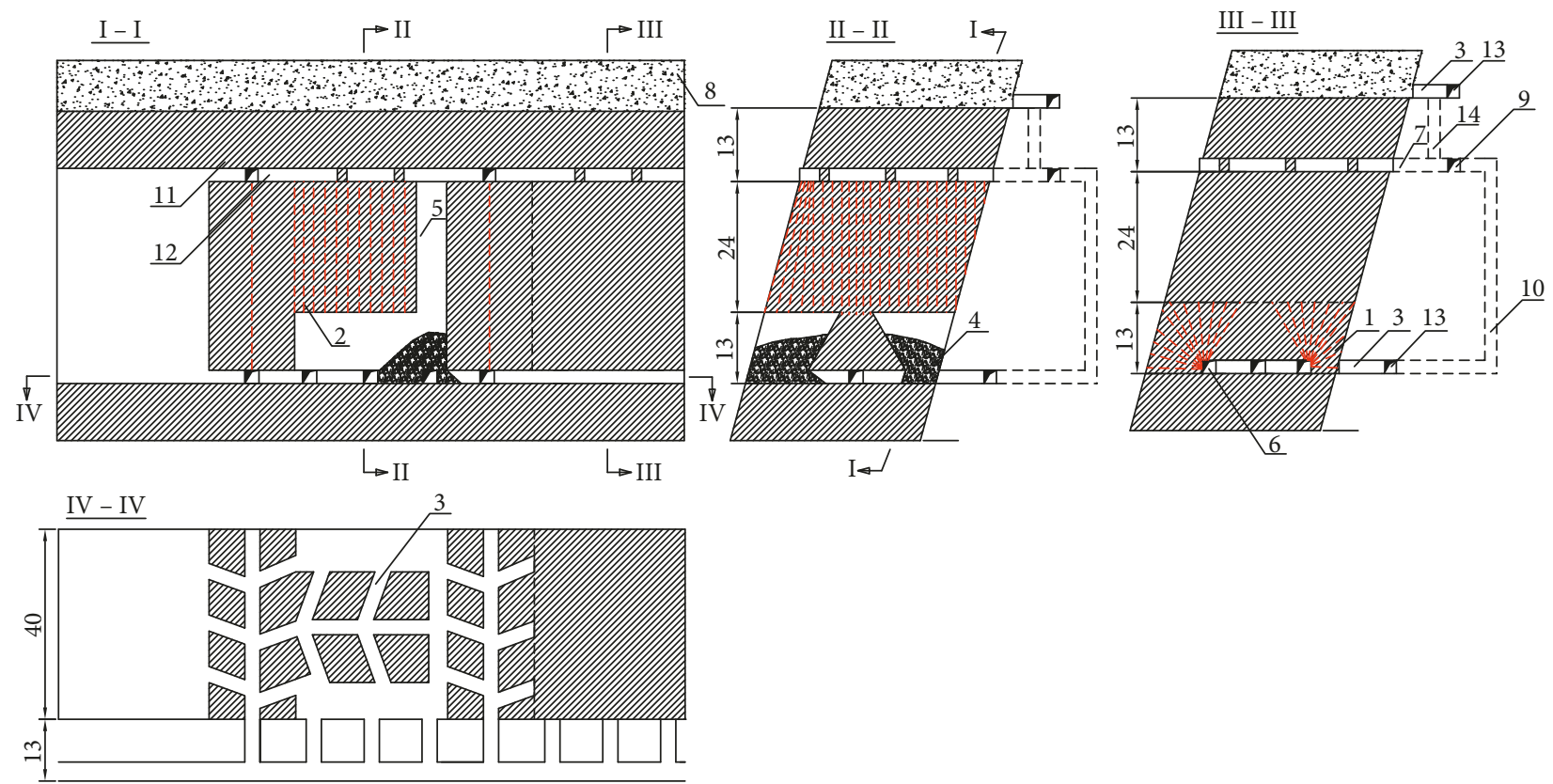

Ore body

Blasthole

3.7. Waste rock

Caved ore
1-Ore body

2-Blasthole

3-Ore-drawing laneway

4-Caved ore

5-Cutting slot
6-Drilling drift

7-Roof-cutting laneway

8 -Waste rock

9-Connection laneway 10-Drop shaft
11-Temporary crown pillar

12-Roof-cutting laneway

13-Haulage laneway

14-Ventilation shaft

FIGURE 2: Sublevel caving mining method used in the Hongling lead-zinc mine (unit: $\mathrm{m}$ ). 


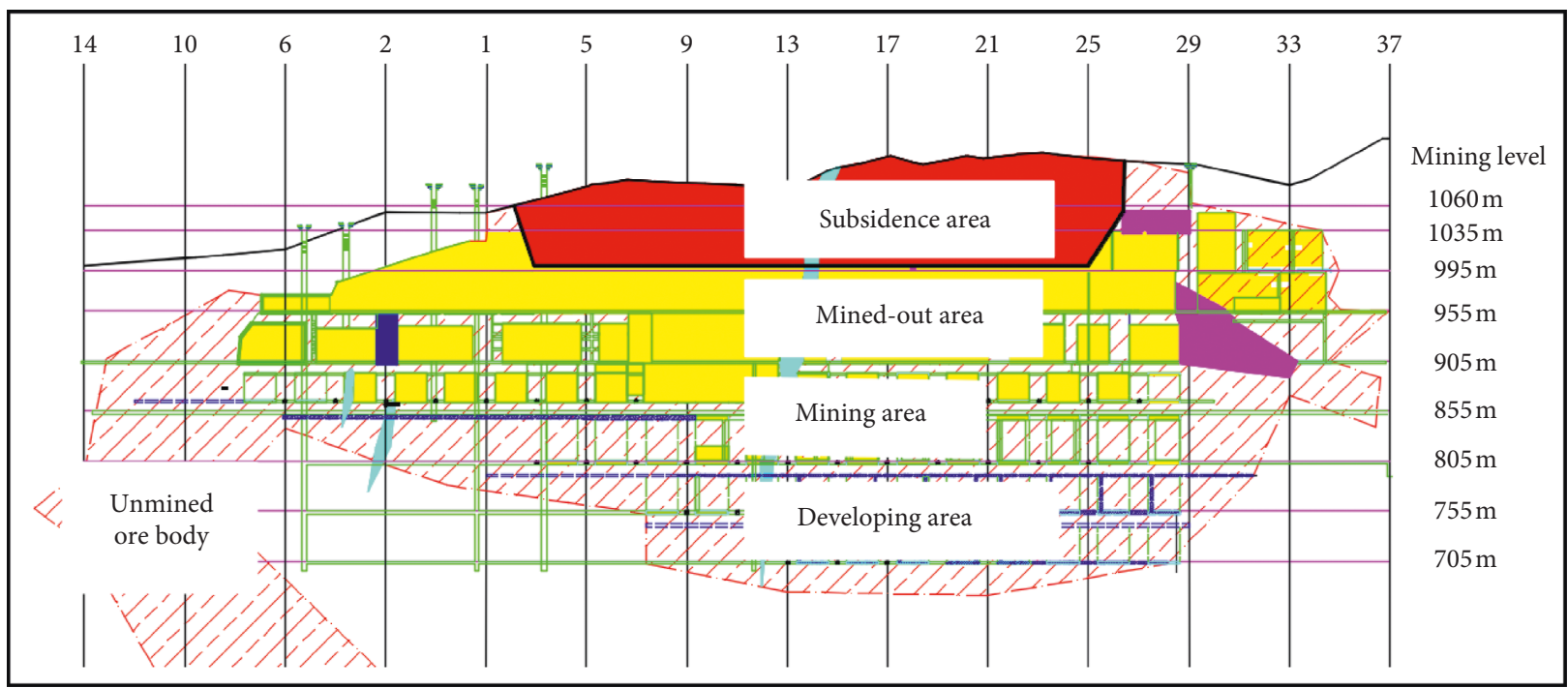

FIgURe 3: Present mining status of $1 \#$ ore body.

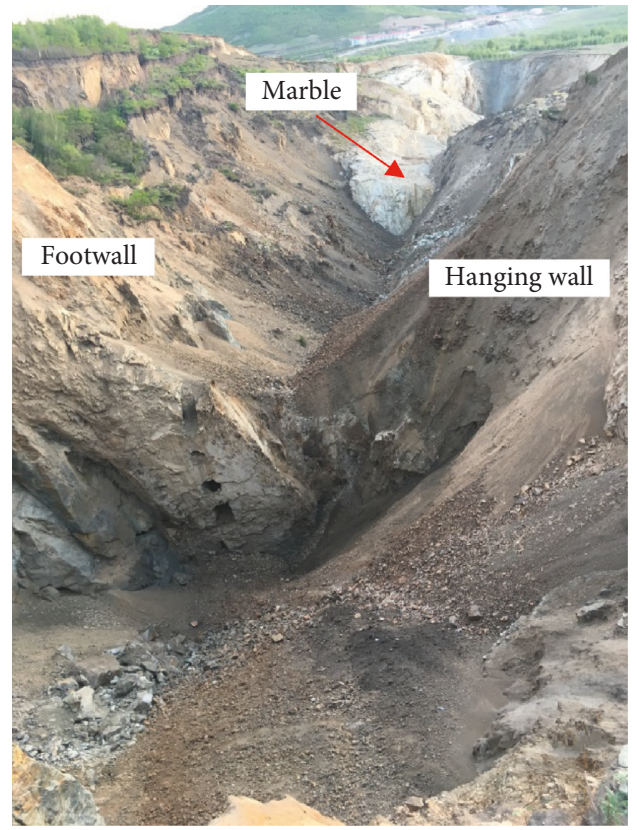

(a)

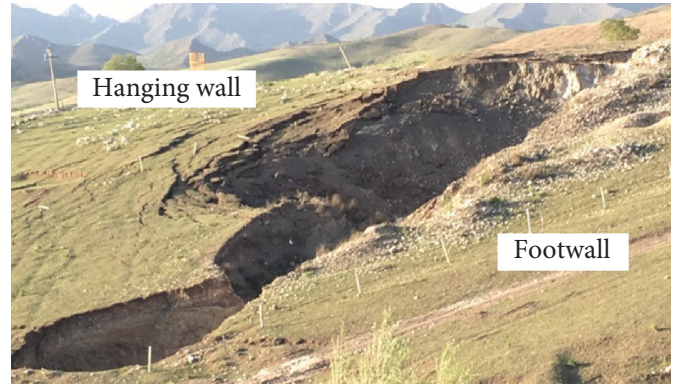

(b)

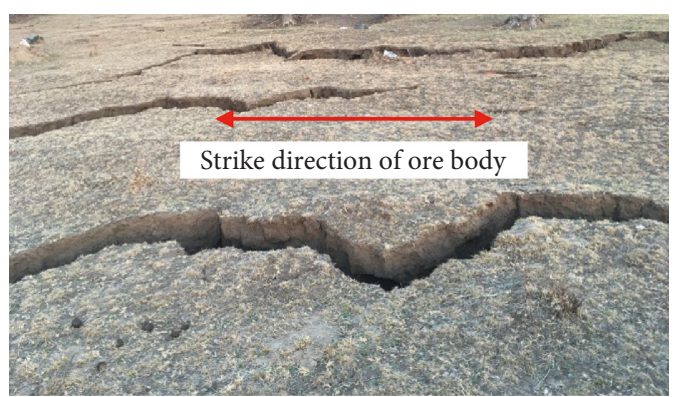

(c)

FIGURE 4: Subsidence pits and tensile cracks in ground surface induced by underground mining. (a) 1\# subsidence pit. (b) 2 \# subsidence pit. (c) Tensile cracks in ground surface of hanging wall.

$$
\begin{gathered}
\bar{\sigma}_{\text {max }}=\frac{-\bar{F}^{\mathrm{n}}}{A}+\frac{\left|\bar{M}^{\mathrm{s}}\right| \bar{R}}{I}, \\
\bar{\tau}_{\text {max }}=\frac{\left|\bar{F}^{\mathrm{s}}\right|}{A}+\frac{\left|\bar{M}^{\mathrm{n}}\right| \bar{R}}{J},
\end{gathered}
$$

where $\bar{R}, A, I$, and $J$ are the radius, area, moment of inertia, and polar moment of the bond cross-section; $\bar{F}^{\mathrm{n}}, \bar{F}^{\mathrm{s}}$ and $\bar{M}^{\mathrm{n}}$, $\bar{M}^{s}$ are the axial- and shear-directed forces and moments, respectively; and $\bar{M}^{\mathrm{n}}=0$ for the PFC2D model.

If the maximum tensile stress of parallel bond exceeds its tensile strength $\left(\bar{\sigma}_{\max } \geq \bar{\sigma}_{\mathrm{c}}\right)$ or the maximum shear stress of parallel bond exceeds its shear strength $\left(\bar{\tau}_{\max } \geq \bar{\tau}_{\mathrm{c}}\right)$, then the parallel bond breaks, leading to the formation of a microtensile or shear crack. When many adjacent microcracks occur, they will connect with each other and form the macrocracks, leading to the failures of intact material, and then the cement behavior was replaced by the grain behavior. Therefore, the PFC model is suitable and reliable for modeling the mechanical behaviors of discrete backfill material (using discrete grains) and intact rock mass (using PBM) and also for simulating the interaction between backfill material and rock mass. 
TABle 1: Mechanical parameters of rock masses.

\begin{tabular}{lccc}
\hline Macro parameters & $\begin{array}{c}\text { Ore } \\
\text { body }\end{array}$ & Slate & Marble \\
\hline Density, $\rho\left(\mathrm{kg} / \mathrm{m}^{3}\right)$ & 3556 & 2770 & 2660 \\
Uniaxial compression strength, $\sigma_{\mathrm{c}}$ & 20.01 & 10.43 & 5.98 \\
$(\mathrm{MPa})$ & 25.12 & 15.85 & 14.71 \\
Young's modulus, $E(\mathrm{GPa})$ & 0.19 & 0.21 & 0.27 \\
Poisson's ratio, $v$ & & & \\
\hline
\end{tabular}

In order to really simulate the mechanical behaviors of rock mass using PFC model, a set of appropriate microscopic parameters were firstly determined. The calibration of microscopic parameters can be achieved by carried out a set of "trial and error" tests [41]: a numerical model with a length of $50 \mathrm{~mm}$ and a height of $100 \mathrm{~mm}$ was firstly established, and then a set of uniaxial compression tests were carried out by adjusting the microscopic parameters, until the PFC model exhibits nearly the same uniaxial compression strength, Young's modulus, and Poisson's ratio as that of rock masses shown in Table 1. The final calibration results of microscopic parameters are shown in Table 2.

According to the geological profile of exploration line 5 in the Hongling lead-zinc mine, a two dimensional numerical model containing 36,199 particles was established by PFC2D to simulate the surface subsidence induced by underground mining, as shown in Figure 5. In the numerical model, the elevation of $+500 \mathrm{~m}$ is set as the origin of the $y$ axis, and the left boundary of the model is set as the origin of the $x$ axis. The horizontal width of the model is $1000 \mathrm{~m}$, and the height of the left and right boundaries are $516 \mathrm{~m}$ and $630 \mathrm{~m}$, respectively. In order to improve the computational accuracy and efficiency, the hanging wall and footwall are divided into two regions to set the radius of particles. The radii of particles in zones I and II are $1.0 \sim 3.0 \mathrm{~m}$ and $1.5 \sim 4.5 \mathrm{~m}$, respectively, and the radii of particles in both marble and ore body are $0.5 \sim 1.5 \mathrm{~m}$.

3.2. Model Boundary Conditions. Before the numerical simulation of underground mining, the in situ stress should be firstly applied to the model. The vertical principal stress was directly set as gravity because both them have a similar value at the same depth according to equation (1). However, the direction of horizontal principal stress is not in the same plane as the strike direction of ore body; thus, the principal stress should be firstly projected to the dip direction of ore body before applied to the model. Because the average values of the ore body strike and the orientation of horizontal

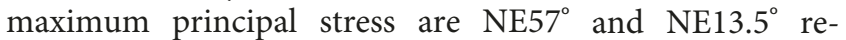
spectively, the angle between the ore body strike and the horizontal maximum principal stress can be approximately considered as: $\theta=57^{\circ}-13.5^{\circ}=43.5^{\circ}$. Therefore, the horizontal in situ stress applied to the model can be determined according to equations (2) and (3) as follows:

$$
\sigma_{\mathrm{h}}=\sigma_{\mathrm{Hmax}} \sin ^{2}(\theta)+\sigma_{\mathrm{Hmin}} \cos ^{2}(\theta)=0.0244 h+5.61 .
$$

The boundary conditions of the PFC model are shown in Figure 5. The wall boundary is adopted at the bottom of the model, and the particle boundary is adopted on both
TABLE 2: Microscopic parameters of the PFC model.

\begin{tabular}{|c|c|c|c|}
\hline Micro parameters & Ore body & Slate & Marble \\
\hline $\begin{array}{l}\text { Particle contact modulus, } \\
E_{\mathrm{c}}(\mathrm{GPa})\end{array}$ & 19.03 & 12.36 & 11.37 \\
\hline Particle stiffness ratio, $k_{\mathrm{n}} / k_{\mathrm{s}}$ & 1.8 & 2.0 & 2.5 \\
\hline $\begin{array}{l}\text { Particle friction } \\
\text { coefficient, } \mu\end{array}$ & 0.5 & 0.5 & 0.5 \\
\hline $\begin{array}{l}\text { Parallel-bond radius } \\
\text { multiplier, } \bar{\lambda}\end{array}$ & 1.0 & 1.0 & 1.0 \\
\hline $\begin{array}{l}\text { Parallel-bond modulus, } \bar{E}_{c} \\
(\mathrm{GPa})\end{array}$ & 19.03 & 12.36 & 11.37 \\
\hline $\begin{array}{l}\text { Parallel-bond stiffness } \\
\text { ratio, } \bar{k}_{\mathrm{n}} / \bar{k}_{\mathrm{s}}\end{array}$ & 1.8 & 2.0 & 2.5 \\
\hline Normal strength, $\bar{\sigma}(\mathrm{MPa})$ & $13.89 \pm 2.78$ & $6.56 \pm 1.31$ & $3.49 \pm 0.70$ \\
\hline Shear strength, $\bar{\tau}(\mathrm{MPa})$ & $20.84 \pm 4.17$ & $9.84 \pm 1.97$ & $5.24 \pm 1.05$ \\
\hline
\end{tabular}

sides of the model for the purpose of applying nonuniform in situ stress; thus, two columns of boundary particles with a radius of $1 \mathrm{~m}$ were generated on both sides of the model. Since the stress cannot be applied directly to the boundary particle in PFC model, the in situ stress applied to the boundary particle must be firstly transformed to force [43]. According to equation (5), the horizontal force applied to the boundary particle with an ordinate of $y$ can be expressed as

$$
F_{\text {ball }}=2 r t[0.0244(H-y)+5.61]
$$

where $F_{\text {ball }}$ is the horizontal force applied to each boundary particle; $r$ and $t$ are the radius and thickness of the boundary particle, respectively; $y$ is the ordinate of the boundary particle; and $H$ is the height of the model boundary, which is $516 \mathrm{~m}$ and $630 \mathrm{~m}$ for the left and right boundary in the present study.

The in situ stress initialization process can be divided into three stages. Stage 1: the displacement of both sides and bottom boundary were firstly fixed, and the gravity was subsequently applied to every particle of the model, and finally the model was run to balance. Stage 2: the horizontal displacement of left and right boundary particles was released, and then a time step was run in order to determine the unbalanced force of each boundary particle induced by gravity, and finally the unbalanced force of each boundary particle was obtained by using the embedded FISH programming language in PFC. Stage 3: an opposite force against the unbalance force was applied to each boundary particle to rebalance the model, and then the opposite force was slowly increased until it reached the value obtained by equation (6), and finally sufficient time steps were run to make the model reach to the equilibrium state.

3.3. Simulation Schemes and Measurement Schemes. In this study, three different excavation cases were simulated by PFC2D to investigate the mechanism of surface subsidence and backfill material movement induced by underground mining, and the same numerical model was used for three cases for the sake of comparison of simulation results. The detailed descriptions of three excavation cases are as follows: 


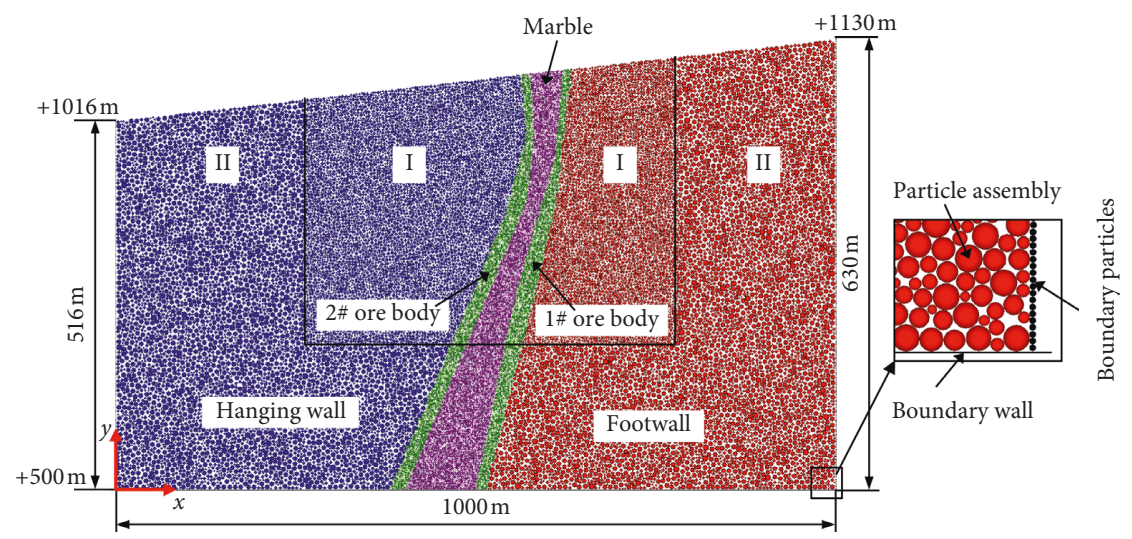

FIgURe 5: PFC numerical model and boundary conditions.

Case 1. The ore body was excavated from ground surface to mining level $705 \mathrm{~m}$ by sublevel caving mining method, and each excavation layer is set as $10 \mathrm{~m}$ to reduce the excavation effect.

Case 2. According to the present mining status of the Hongling lead-zinc mine, the majority of ore body above mining level $905 \mathrm{~m}$ was excavated, and a subsidence area formed in ground surface. Therefore in simulation model, the ore body above mining level $905 \mathrm{~m}$ was firstly excavated by the sublevel caving mining method, and then the minedout area was backfilled by the noncemented tailings. An insulating pillar with thickness of $20 \mathrm{~m}$ beneath the subsidence area was reserved to maintain the stability of collapsed rock mass and backfill material, and then the ore body was continued to excavate until mining level $705 \mathrm{~m}$ by the sublevel caving mining method. In this case, each excavation layer is also $10 \mathrm{~m}$.

Case 3. The mining sequence of case 3 is the same as that of case 2, i.e., the ore body above mining level $905 \mathrm{~m}$ was firstly excavated by sublevel caving mining method, and the mined-out area was backfilled by the noncemented tailings, and an insulating pillar was also reserved beneath the subsidence area. The difference between case 2 and case 3 is that the ore body between mining levels $905 \mathrm{~m}$ and $705 \mathrm{~m}$ was excavated by cut-and-fill mining method in case 3 .

Among these three excavation cases, case 1 was implemented to investigate the mechanical mechanism of surface subsidence duo to underground mining, and cases 2 and 3 were implemented to investigate the movement law of backfill material and rock strata due to underground mining with different mining methods. For cases 2 and 3, the minedout area above $905 \mathrm{~m}$ was backfilled by the noncemented tailings after the ore body above $905 \mathrm{~m}$ was excavated, which can be achieved in PFC through the following ways: after the ore body above $905 \mathrm{~m}$ was excavated, all particles of the model were fixed, and a large number of particles, which were restricted by two boundary wall, were generated above the mined-out area; then sufficient time steps were run to consolidate the backfill material, and finally the restricted walls and the backfill particles beyond the mined-out area were deleted. For case 3, the cemented tailings were used as the filling material in cut-and-fill mining method, which can be achieved by reducing the strength and contact stiffness of the ore body. The macroscopic and microscopic properties of the backfill material are presented in Table 3 .

In order to record the stress and displacement evolution during excavation process, a set of stress measurement circles and displacement measurement points were set in the model, as shown in Figure 6. The radius of stress measurement circles in ground surface of hanging wall (A1 A4) and footwall $(\mathrm{B} 1 \sim \mathrm{B} 4)$ is $12.5 \mathrm{~m}$; the radius of stress measurement circles in surrounding rock of hanging wall $(\mathrm{C} 1 \sim \mathrm{C} 3)$ and footwall $(\mathrm{E} 1 \sim \mathrm{E} 3)$ is $20 \mathrm{~m}$; the radius of stress measurement circles in ore body is $30 \mathrm{~m}$. Twenty-two displacement measurement points are set in ground surface of hanging wall (F1 F22), and the distance between two measurement points is $25 \mathrm{~m}$; fifteen displacement measurement points are set in ground surface of footwall (G1 G15), and the distance between two measurement points is $25 \mathrm{~m}$.

\section{Numerical Results and Analysis}

4.1. Surface Subsidence Mechanism. In this section, the simulation case 1 mentioned in Section 3.3 was carried out to investigate the mechanical mechanism of surface subsidence induced by underground mining. Figure 7 shows the surface subsidence process and the corresponding force evolution during excavation simulation process, where the left figures show the failure process of the numerical model, and the middle and right figures are the parallel-bond force and contact force distribution, respectively. In the parallel-bond force distribution figures, the red and black denote the tensile and compressive force, respectively, and the thickness of the line denotes the magnitude of the force. However, the contact force distribution figures can only show the compressive force because the contact between two particles cannot transmit tensile force.

It can be seen from Figure 7(a) that the marble becomes a cantilever beam after ore body above $995 \mathrm{~m}$ is excavated. The marble cantilever beam collapses when the mining level reaches $905 \mathrm{~m}$ due to the low strength of the 
TABle 3: Macroscopic and microscopic properties of the filling material.

\begin{tabular}{lccccccccc}
\hline \multirow{2}{*}{ Filling material } & \multicolumn{4}{c}{ Macroscopic parameter } & \multicolumn{4}{c}{ Microscopic parameter } \\
& $\rho\left(\mathrm{kg} / \mathrm{m}^{3}\right)$ & $\sigma_{\mathrm{c}}(\mathrm{MPa})$ & $E(\mathrm{GPa})$ & $\nu$ & $r(\mathrm{~m})$ & $E_{\mathrm{c}}(\mathrm{GPa})$ & $k_{\mathrm{n}} / k_{\mathrm{s}}$ & $\bar{\sigma}(\mathrm{MPa})$ & $\bar{\tau}(\mathrm{MPa})$ \\
\hline Noncemented & 1880 & - & - & - & $0.1 \sim 0.2$ & 0.54 & 3 & - & - \\
Cemented & 2150 & 2 & 3 & 0.35 & $0.5 \sim 1.5$ & 0.54 & 3 & $1.12 \pm 0.22$ & $1.68 \pm 0.34$ \\
\hline
\end{tabular}

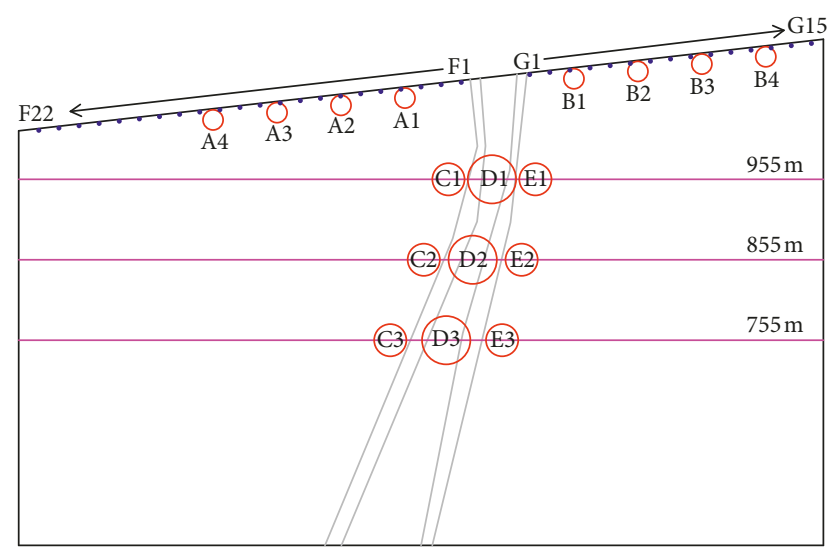

Figure 6: Layout of stress measurement circles and displacement measurement points. A1 A4, B1 B4, C1 C4, D1 D3, and E1 E3 are stress measurement circles; F1 F22 and $\mathrm{G} 1 \sim \mathrm{G} 15$ are displacement measurement points.

marble, leading to the formation of collapse pit in ground surface, as shown in Figure 7(b). At the same time, two tensile stress concentration zones appear in ground surface of both sides of the collapse pit, and a compressive stress concentration zone appears in the bottom of the collapse pit. Since the tensile strength of rock mass is much smaller than the compressive strength, the failures are easier to occur in tensile stress concentration zone. Therefore, with the continued excavation of ore body, the toppling failure occurs in hanging wall, as shown in Figure $7(\mathrm{c})$. After the toppling failure of hanging wall, a part of mined-out area is filled by the waste rock collapsing from hanging wall and marble, leading to the formation of a large collapse pit in ground surface, as shown in Figure 7(d). In this case, the tensile stress concentration zone still appears in ground surface of hanging wall. It indicates that toppling failure may further occur in hanging wall with the continued excavation of ore body. Moreover, it can also be seen from the comparison between parallel-bond force and contact force in Figure 7 that the contact force still exists in the collapsed rock in mined-out area although the parallel bond breaks. In this case, the collapsed waste rock cannot bear tensile stress anymore but can still bear compressive stress, especially when the lateral displacement is restricted. As shown in Figure 7(d), the collapsed rock is restricted by hanging wall and footwall, but in turn, the collapsed rock can provide support force for the surrounding rock to some extent. It indicates that the filling materials such as tailings and waste rocks in the minedout area can to some extent restrict the horizontal displacement of surrounding rock, thus limiting the further failures of surrounding rock during ore body excavation. Therefore, backfilling the collapse pit and mined-out area is beneficial to control the displacement and failure of hanging wall and footwall.

Figure 8 presents the comparison of numerical results and site observation. As shown in Figure 8(a), before the residual ore body above $955 \mathrm{~m}$ is recovered, the marble can remain stable, and no obvious subsidence and cracks appear in ground surface. As shown in Figure 8(b), a large mined-out area forms between hanging wall and footwall after a large number of ore bodies are extracted from underground, leading to the toppling failure in hanging wall. The occurrence of toppling failure results in a set of tensile cracks in ground surface of hanging wall, which extend along the strike direction of ore body. As shown in Figure $8(\mathrm{c})$, after the toppling failure, large surface subsidence occurs in hanging wall, and a large collapse pit appears in ground surface. It can be seen that the numerical results are in good agreement with site observations, indicating that the established numerical model can be used to study the mechanism of surface subsidence induced by underground mining in the Hongling lead-zinc mine.

The evolutional curves of horizontal stress in ground surface of hanging wall and footwall are shown in Figure 9. In the figure, the simulation time begins when the ore body is excavated, and the positive value denotes the compressive stress. With the excavation of ore body, the horizontal tectonic stress is released, leading to the rapid decrease of horizontal stresses in ground surface of hanging wall and footwall. The stress measurement circle closer to the mined-out area shows a larger stress reduction. With the further excavation of ore body, the horizontal stress in ground surface changes from compressive stress to tensile stress, resulting in the formation of tensile stress concentration zones in ground surface of hanging wall and footwall, as shown in Figure 7(b). When the tensile stress reaches the tensile strength of rock mass, tensile cracks begin to occur in ground surface, and the propagation and coalescence of tensile cracks result in the toppling failure in hanging wall, as shown in Figure 7(c). After the toppling failures in hanging wall, the horizontal stress in measurement circles $\mathrm{A} 1$ and $\mathrm{A} 2$ drops to zero, and the horizontal stress in measurement circles A3 and A4 continues to decrease, which may result in further failures in ground surface of hanging wall. However, after the toppling failures in hanging wall, the horizontal stress in ground surface of footwall increases with the continued excavation of ore body, as shown in Figure 9(b). This may be attributed to the collapsed rock in the mined-out area, which can provide the support force for the footwall to an extent. 

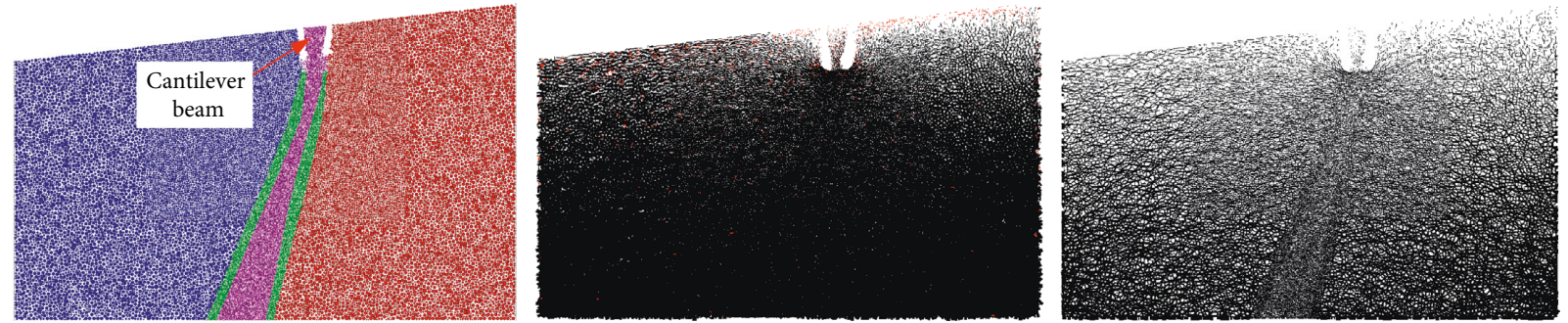

(a)
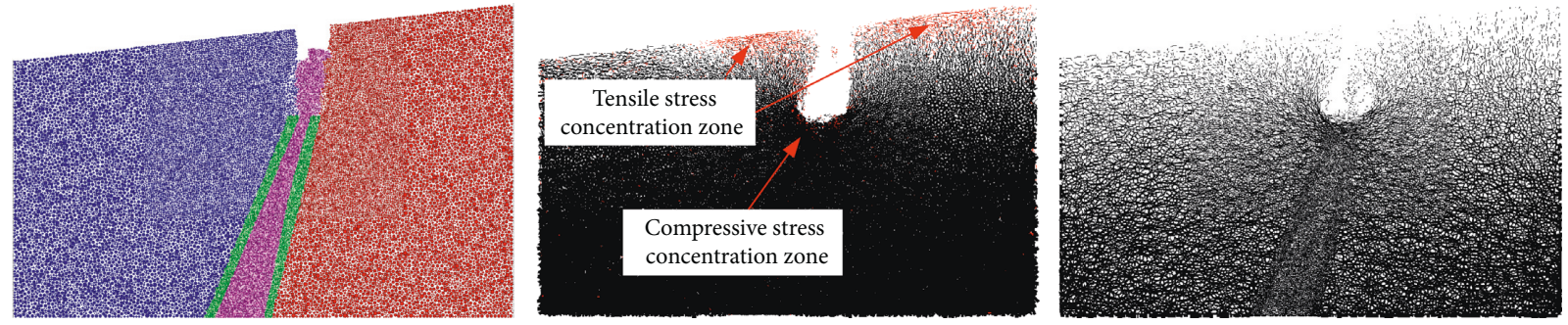

(b)
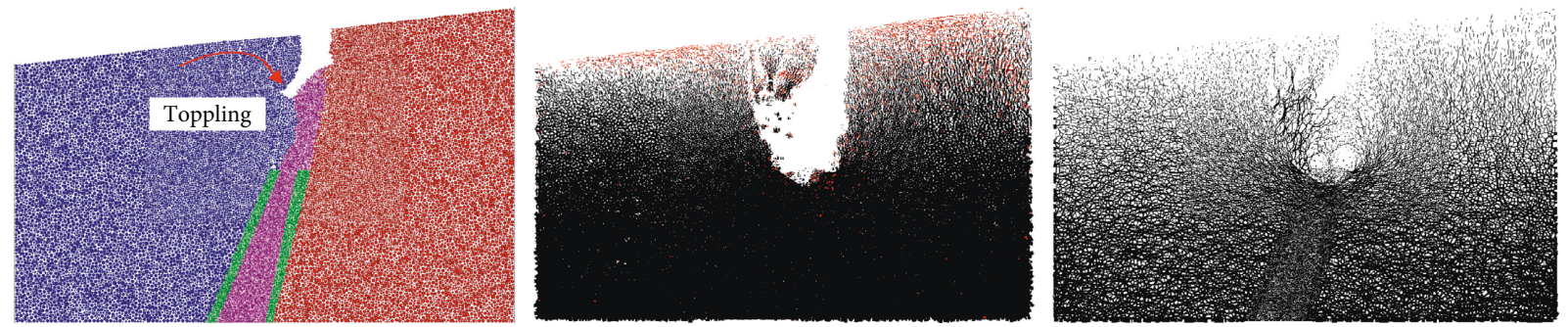

(c)
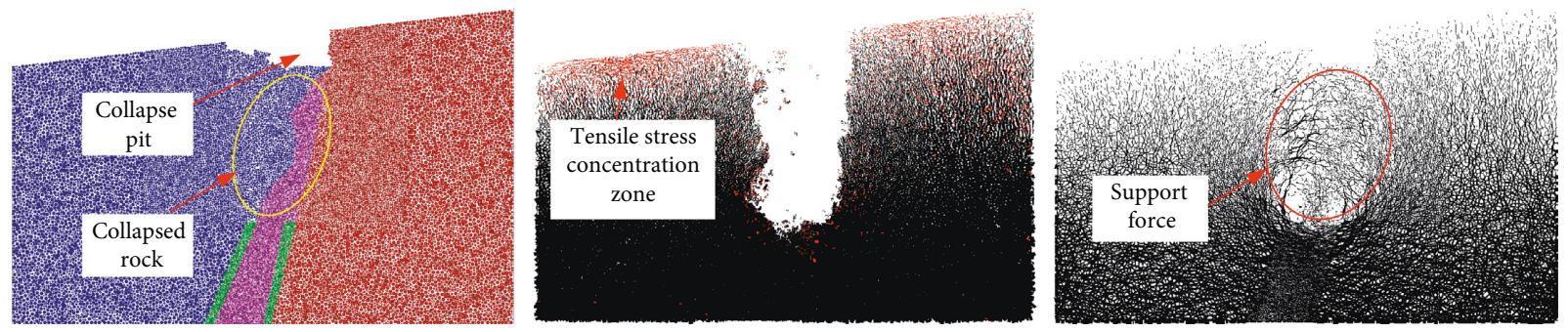

(d)

FIGURE 7: Ground surface subsidence process and the corresponding force evolution. Left figures: ground surface subsidence; middle figures: parallel-bond force (red and black denote the tensile and compressive force, respectively); right figures: contact force. (a) After excavation of $995 \mathrm{~m}$. (b) After excavation of $905 \mathrm{~m}$. (c) After excavation of $805 \mathrm{~m}$. (d) After excavation of $705 \mathrm{~m}$.

Figure 10 shows the evolutional curves of horizontal stress in surrounding rock and ore body. The horizontal stress in the hanging wall, footwall, and ore body has the same evolution law, i.e., the horizontal stress increases first (before the excavation reaches the measurement circle) and then decreases (after the excavation reaches the measurement circle) with the increase of excavation depth, and it finally oscillates around $2 \mathrm{MPa}$. This residual stress is exactly the support force provided by the collapsed waste rock. In addition, the compressive stress concentration in ore body is more obvious than that in surrounding rock of hanging wall and footwall, which may result in the crushing and upheaval in the bottom of mined-out area.
Figure 11 presents the ground surface displacement after each mining level is excavated. Before the ore body excavation reaches the mining level $805 \mathrm{~m}$, both vertical and horizontal displacements are very small, and the horizontal displacement in this case is larger than the vertical displacement because before ground surface subsidence, the ground surface displacement is mainly induced by the release of horizontal tectonic stress. However, after the ore body excavation reaches the mining level $805 \mathrm{~m}$, the ground surface displacement increases rapidly due to the toppling failure of hanging wall, and the displacement increases with the increase of mining depth. In this case, the displacement in hanging wall is much larger than that in footwall because 

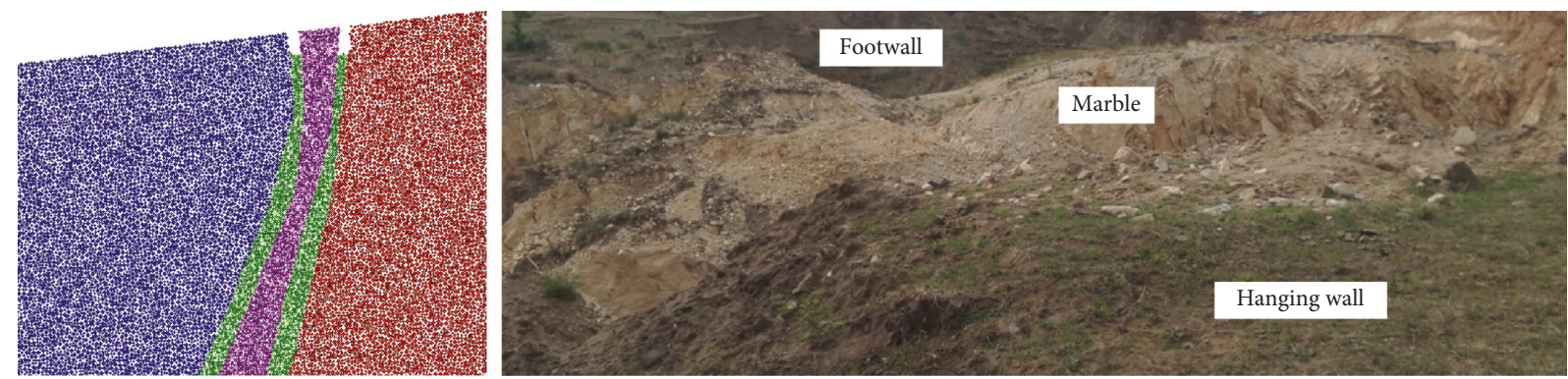

(a)
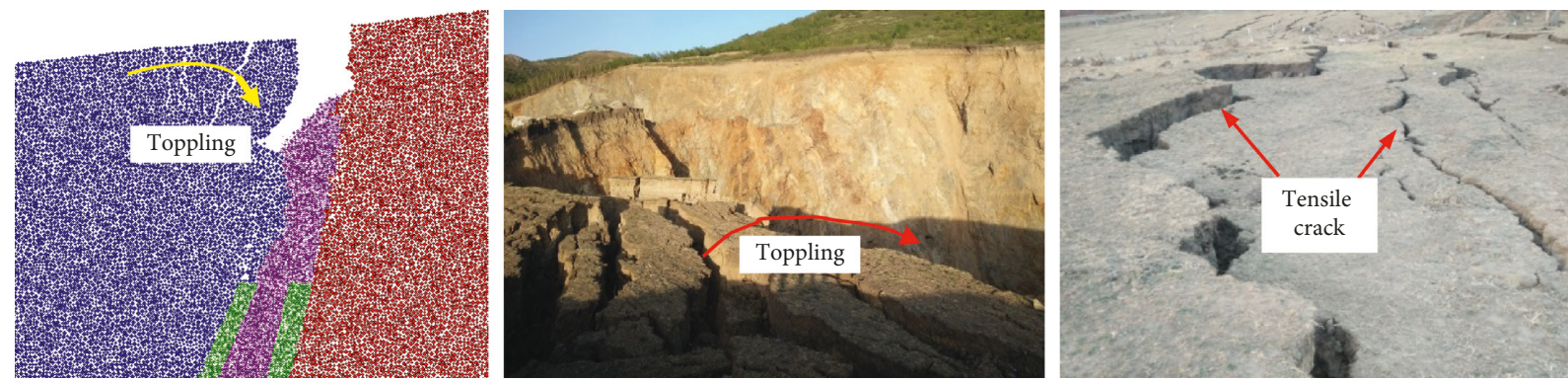

(b)
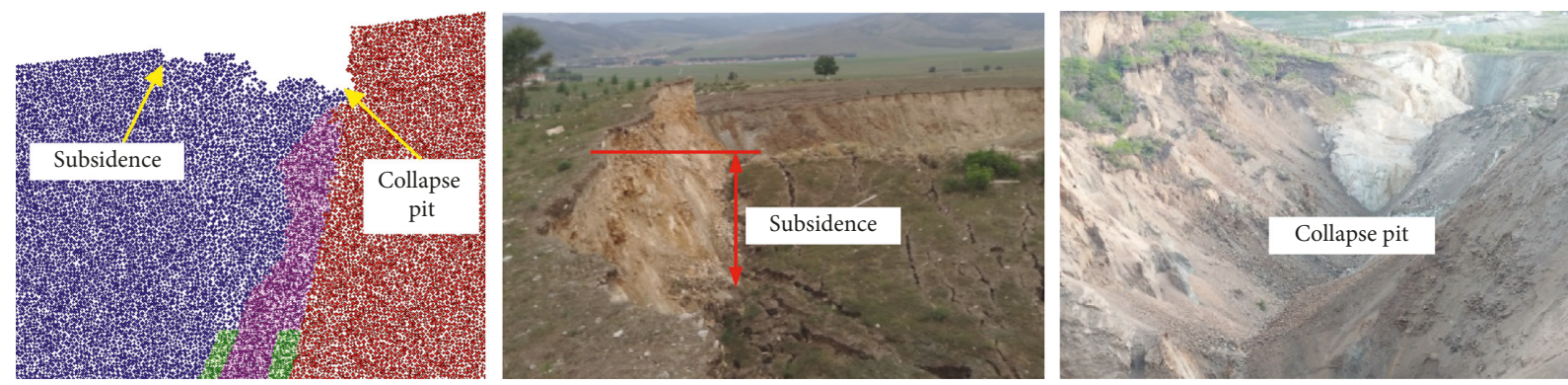

(c)

Figure 8: Comparison of numerical results and site observation. (a) Before marble failure. (b) Toppling failure of hanging wall and induced tensile cracks. (c) Large surface subsidence and collapse pit.

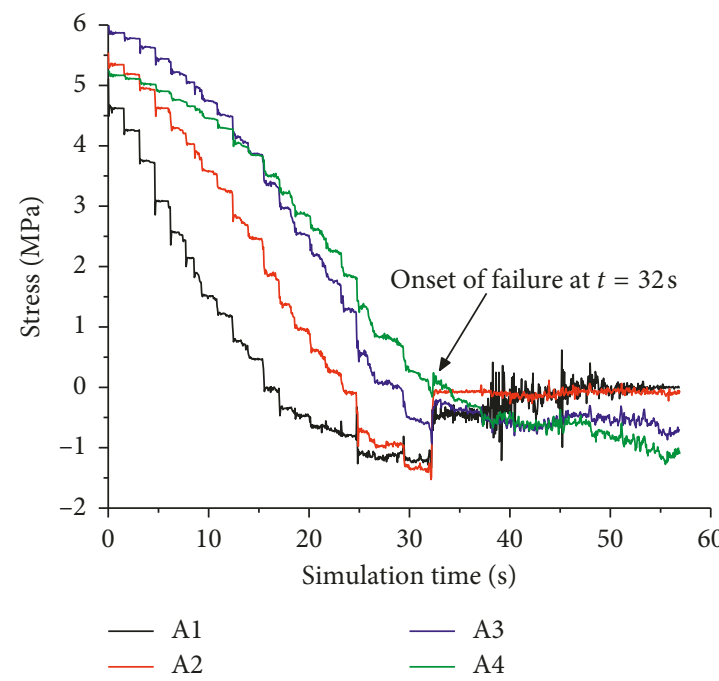

(a)

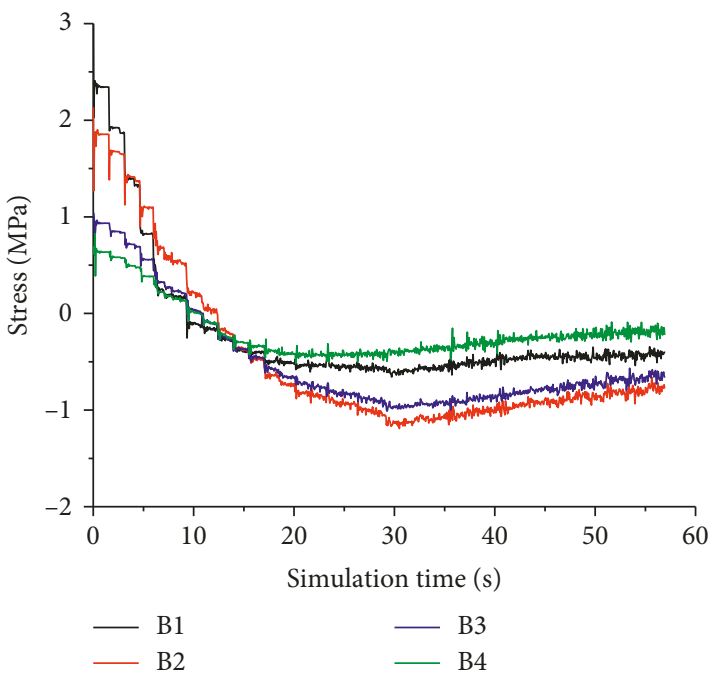

(b)

Figure 9: Horizontal stress evolution of ground surface (positive value denotes the compressive stress). (a) Hanging wall. (b) Footwall. 


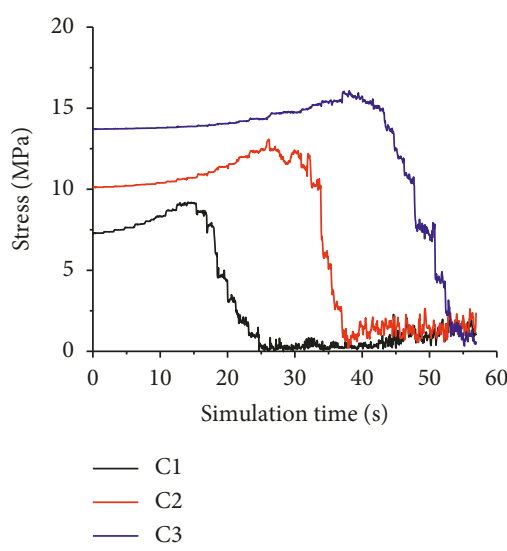

(a)

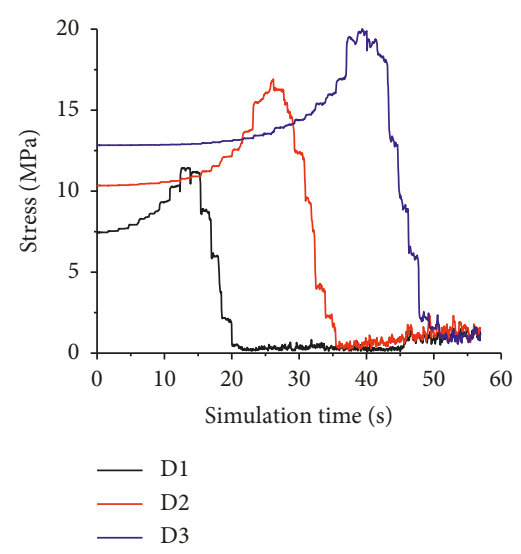

(b)

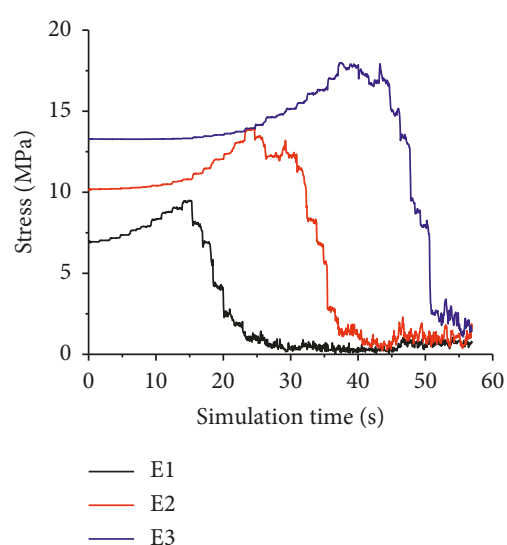

(c)

FIGURE 10: Horizontal stress evolution of surrounding rock and ore body. (a) Hanging wall. (b) Ore body. (c) Footwall.

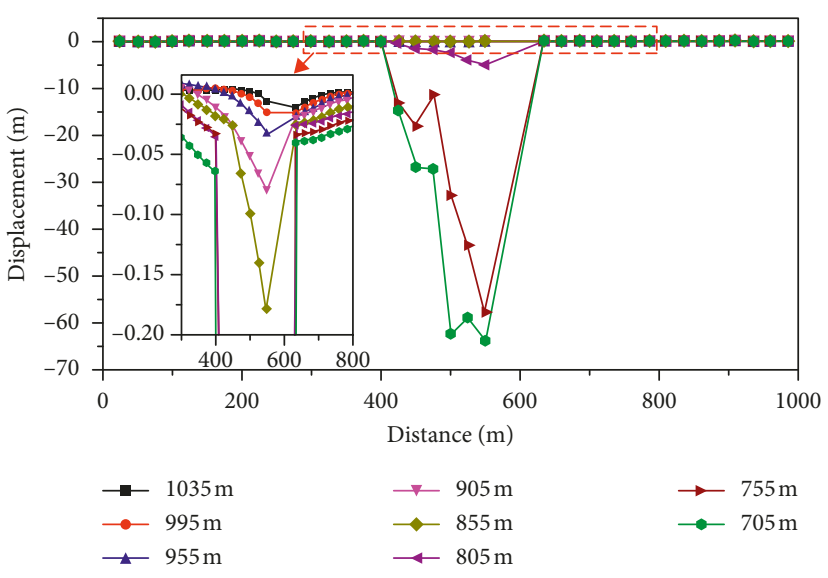

(a)

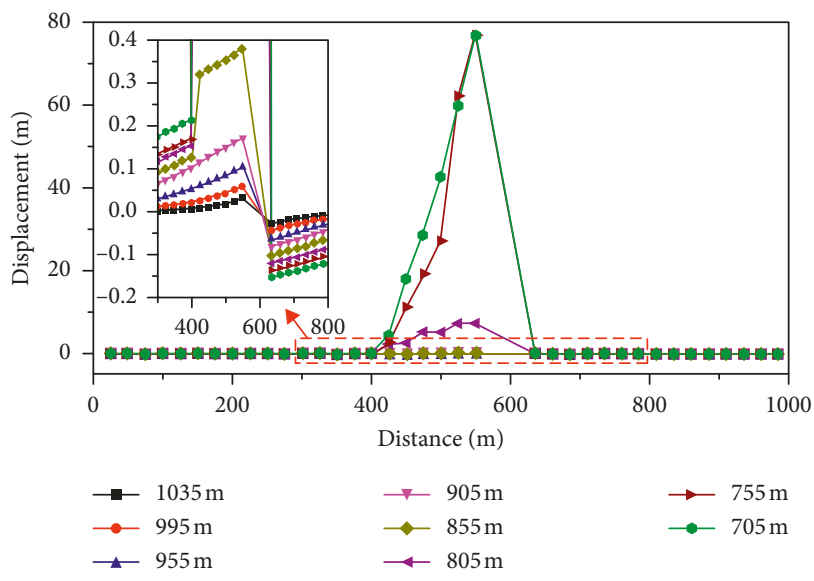

(b)

Figure 11: Ground surface displacement. (a) Vertical displacement. (b) Horizontal displacement.

the surface subsidence mainly occurs in hanging wall, while the displacement in footwall is very small even when the ore body excavation reaches to mining level $705 \mathrm{~m}$.

\subsection{Movement Law of Backfill Material and Rock Strata.} In this section, the simulation cases 2 and 3 mentioned in Section 3.3 were carried out to investigate the movement law of backfill material and rock strata induced by underground mining with different mining methods, and the movement process of backfill material and rock strata during underground mining for cases 2 and 3 are presented in Figure 12.

After the excavation of mining level $905 \mathrm{~m}$, the collapse pit in ground surface was backfilled by the noncemented tailings, and an insulating pillar with thickness of $20 \mathrm{~m}$ was reserved at the bottom of collapse pit. As shown in Figure 12(a), when the sublevel caving mining method is adopted after the backfill of collapse pit, the mined-out area appears beneath the insulating pillar and cannot be backfilled in time. In this case, the pillar loses the support capacity and is crushed due to the combined loading of collapsed waste rock and surrounding rock. The collapsed waste rock and backfill material begin to subside, leading to the occurrence of subsidence pit in ground surface. With the further excavation of ore body, the collapsed waste rock and backfill material continue to subside because the insulating pillar has failed and cannot maintain the stability of collapsed waste rock and backfill material anymore. In this case, the toppling failure occurs in hanging wall due to the occurrence of subsidence pit in ground surface. It is worth mentioning that the backfill material close to the hanging wall is easier to subsidence, i.e., the backfill material subsidence along the direction approximately the same as the dip direction of the ore body. When the mining level reaches $755 \mathrm{~m}$, a large open fracture and a step appear in ground surface of hanging wall due to the toppling failure, and a large collapse pit also appears in ground surface. However, it can be seen from the Figure 12(b) that the backfill material and the surrounding rock can remain stable when the cutand-fill method is adopted because the mined-out area beneath the pillar can be backfilled in time by the cemented 

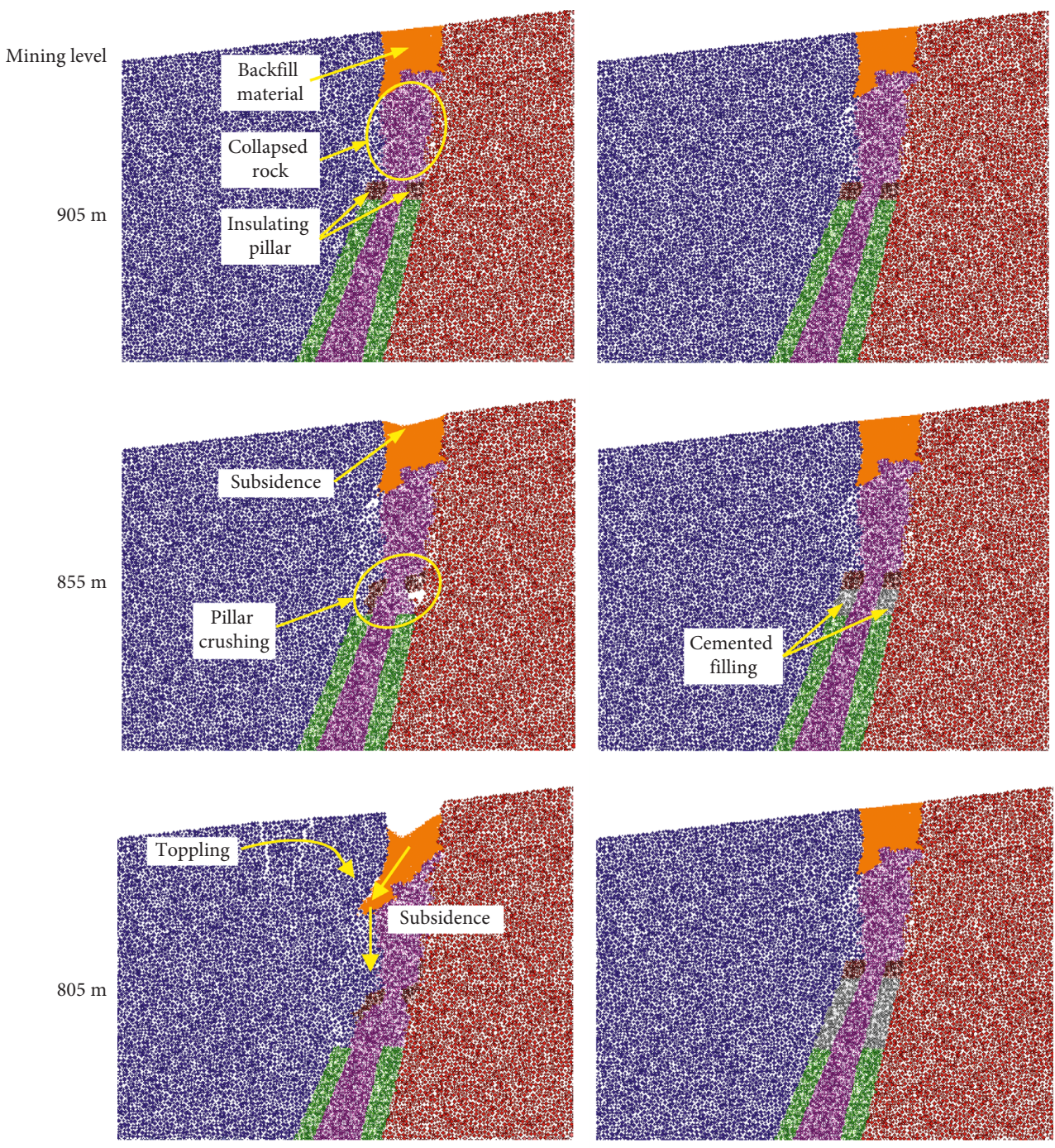

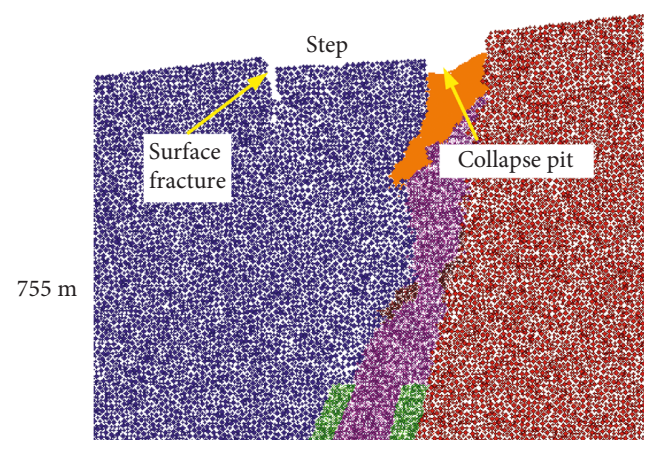

(a)

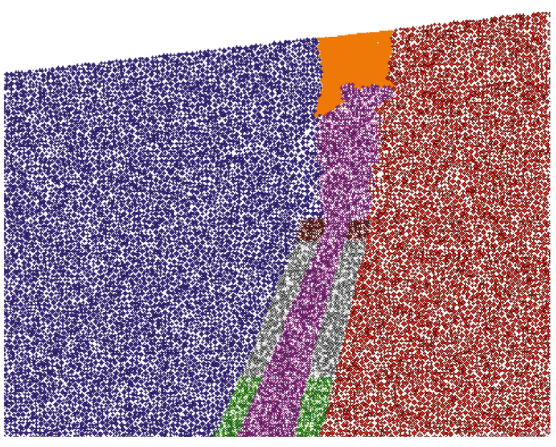

(b)

Figure 12: Movement of backfill material and rock strata during underground mining process. (a) Case 2. (b) Case 3.

tailings after the ore body is excavated. It indicates that the cut-and-fill mining method can efficiently maintain the stability of surrounding rock and backfill material and prevent the occurrence of collapse pit in ground surface.

Figure 13(a) shows the horizontal stress in ground surface of hanging wall. In the figure, the simulation time begins when the ore body beneath the insulating pillar is excavated. With the excavation of ore body beneath the insulating pillar, the horizontal stress in ground surface of hanging wall continues to decrease for case 2 . When the horizontal stress of hanging wall reaches the tensile strength of rock mass, the tensile failure occurs in ground surface of hanging wall, leading to the toppling failure of hanging wall. For case 3, however, the horizontal stress in ground surface of hanging wall increases with the continued excavation of ore body, so no tensile failure occurs in hanging wall in this case. Figure 13(b) shows that the horizontal stress in ground surface of footwall increases with the excavation of ore body 


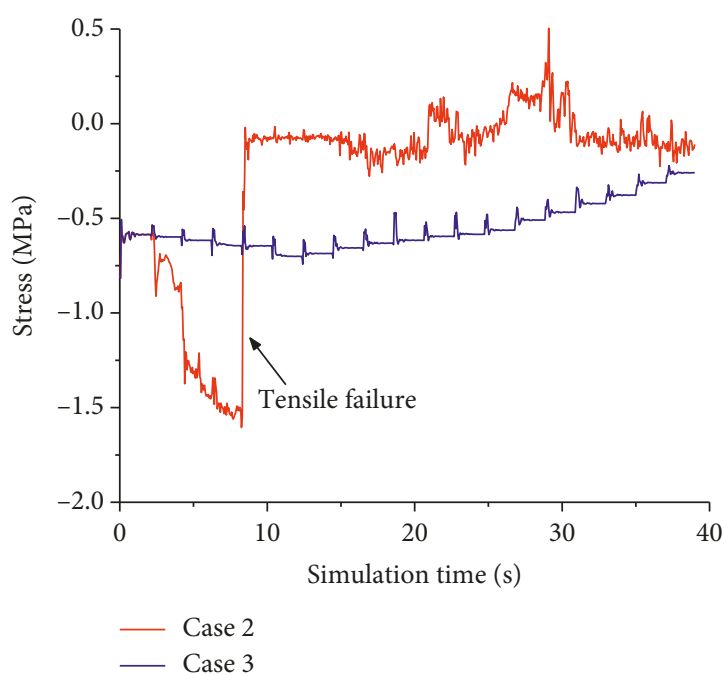

(a)

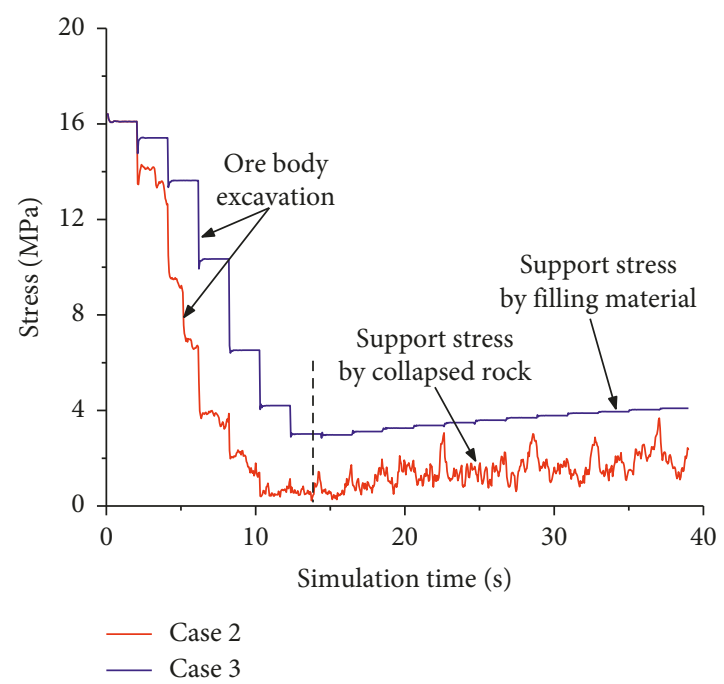

(c)

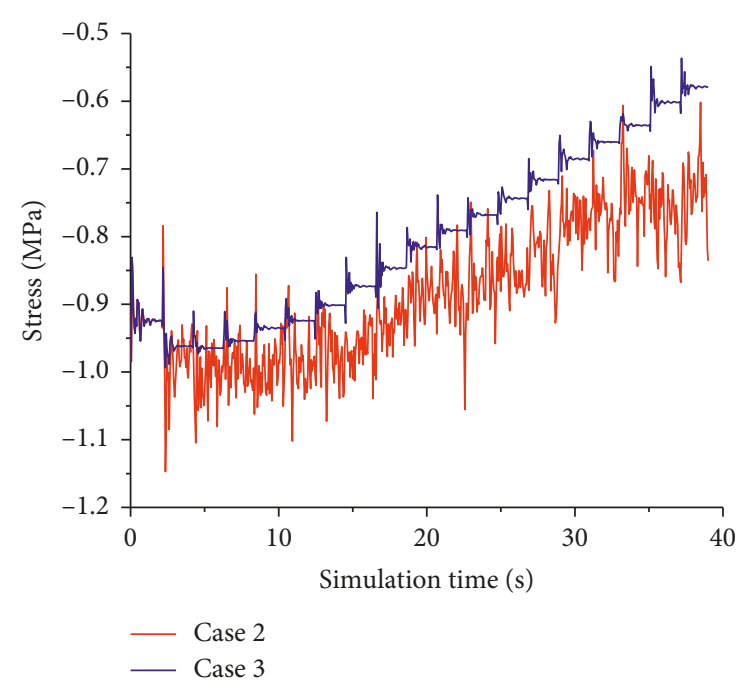

(b)

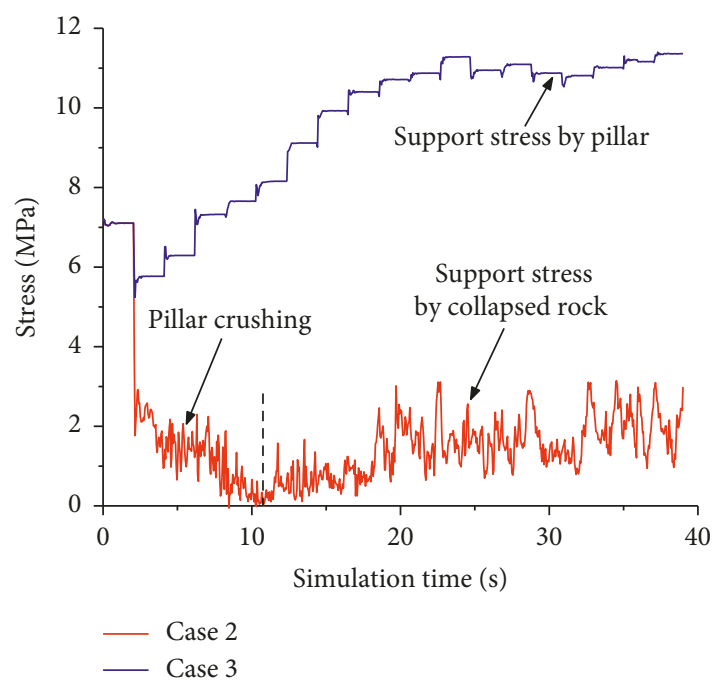

(d)

FIGURE 13: Horizontal stress evolution of ground surface, ore body, and pillar. (a) Ground surface of hanging wall (A2). (b) Ground surface of footwall (B2). (c) Ore body (D2). (d) Insulating pillar.

for both cases 2 and 3, so no tensile failure occurs in ground surface of footwall. Figure 13(c) shows the horizontal stress of ore body. When the ore body is excavated from mining level $905 \mathrm{~m}$ to $855 \mathrm{~m}$, the horizontal stress of ore body at measurement circle D2 deceases with the increase of mining depth. After the ore body within the measurement circle D2 was excavated, the measurement circle D2 was filled by the collapsed waste rock (for case 2) or the cemented filling material (for case 3). In this case, the stress in the measurement circle D2 denotes the support stress provided by collapsed waste rock (for case 2 ) or cemented filling material (for case 3). It can be seen from Figure 13(c) that the support stress provided by cemented filling material is larger than that provided by collapsed waste rock.

In order to monitor the stress evolution of insulating pillar during underground mining, a stress measurement circle with a radius of $10 \mathrm{~m}$ was set in the range of pillar, and the horizontal stress evolution of insulating pillar for both cases 2 and 3 is presented in Figure 13(d). With the excavation of ore body, the horizontal stress of insulating pillar decreases for case 2 due to the crushing of pillar, while it increases for case 3 . It indicates that the insulating pillar can remain stable for case 3 and provide high support force for the surrounding rock, thus preventing the failures of hanging wall and the subsidence of ground surface. For case 2 , after the crushing failure of insulating pillar, the stress in the measurement circle denotes the support stress provided by the collapsed rock. In this case, only a small support stress can be provided by the collapsed rock. Furthermore, it can be found from the comparison of Figures 14(c) and 14(d) that the collapsed waste rock in the mined-out area can only provide about $2 \mathrm{MPa}$ support stress for the surrounding rock for case 2. However, for case 3, the support stress provided by the cemented filling material and the insulating pillar are about $4 \mathrm{MPa}$ and $11 \mathrm{MPa}$, respectively, and the support stress provided by the insulating pillar is much larger than 


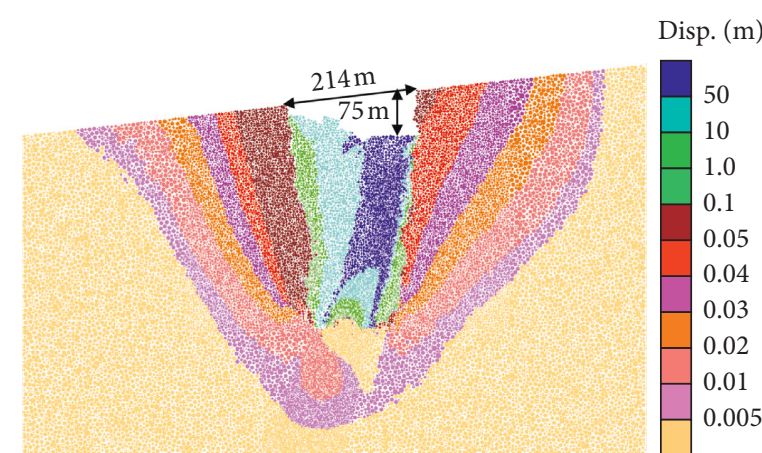

(a)

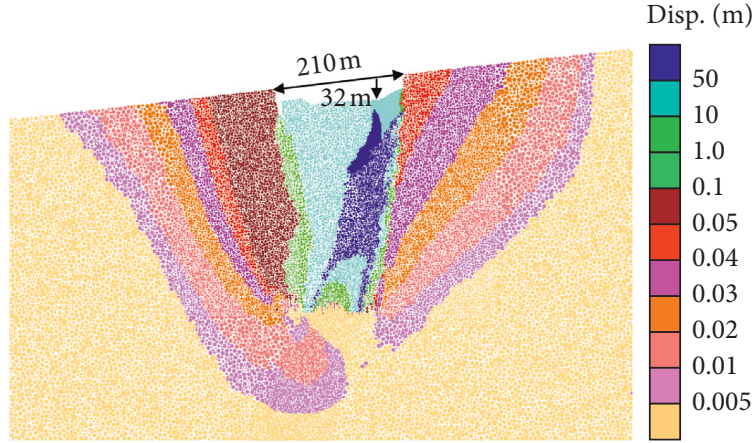

(b)

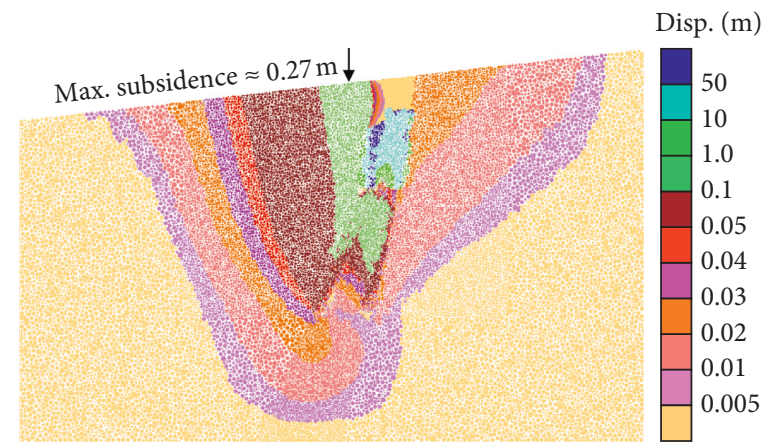

(c)

FIgURe 14: Vertical displacement contour of the model after excavation of mining level $705 \mathrm{~m}$. (a) Case 1. (b) Case 2 . (c) Case 3.

that provided by the cemented filling material. It indicates that when the cut-and-fill mining method is adopted for underground mining, the insulating pillar can provide large support stress for the surrounding rock and maintain the stability of the collapsed waste rock and backfill material in the surface subsidence pit. Therefore, it is of great significance to reserve a reasonable insulating pillar when using the cut-and-fill mining method to excavate the ore body beneath the collapse pit.

Figure 14 presents the vertical displacement contour of three simulation models after excavation of mining level $705 \mathrm{~m}$. The vertical displacement contour for three models exhibits a "V" shape, i.e., the vertical displacement of surrounding rock decreases with the increase of burial depth of rock mass, and the surrounding rock closer to the excavation zone exhibits larger vertical displacement. It is worth mentioning that the vertical displacement in hanging wall and footwall is very small $(<0.1 \mathrm{~m})$ except the collapse pit because the present numerical model is composed of the dense particle assembly, which cannot reproduce the natural joints and fissures in practical rock mass. However, if the detailed in situ data of natural joints and fissures of rock mass can be obtained by borehole logging or window mapping, then the more authentic displacement of rock mass can be modeled by the synthetic rock mass (SRM) model in PFC, in which the natural joints and fissures of rock mass can be reproduced by the smooth joint contact model (SJM) [44-46]. Furthermore, when the ore body is excavated by the sublevel caving mining method without backfilling the mined-out area, a large collapse pit with a width of $214 \mathrm{~m}$ and a depth of $75 \mathrm{~m}$ appears in ground surface after the excavation of $705 \mathrm{~m}$, as shown in Figure 14(a). However, when the mined-out area above level $905 \mathrm{~m}$ is backfilled by the noncemented tailings, if the sublevel caving mining method is still used to excavate the ore body in deep levels, a new collapse pit will appear in ground surface, as shown in Figure 14(b). In this case, the depth of the collapse pit is smaller than that of case 1, indicating that if the sublevel caving method is still used, the backfill material can reduce the depth of collapse pit to some extent but cannot prevent the occurrence of collapse pit. If the mining method is changed to the cut-and-fill method after backfilling of mined-out area, no obvious subsidence pit appears in ground surface, as shown in Figure 14(c), and the maximum subsidence in ground surface is about $0.27 \mathrm{~m}$. It indicates that the cut-and-fill mining method can efficiently control the surface subsidence and prevent the occurrence of collapse pit in ground surface. Therefore, the mining sequence of case 3 is recommended for the Hongling lead-zinc mine to solve the surface subsidence problem.

\section{Practical Application}

Numerical simulation results in the present study indicate that in order to control the further collapse of hanging wall, the current mining method should be changed to the cutand-fill mining method, and the surface subsidence areas should be backfilled in time. In addition, an insulating pillar is needed to reserve beneath the collapsed waste rock to maintain the stability of waste rock layer and backfill material. Based on the numerical results, a proper tailings backfilling scheme is put forward for the Hongling lead-zinc 


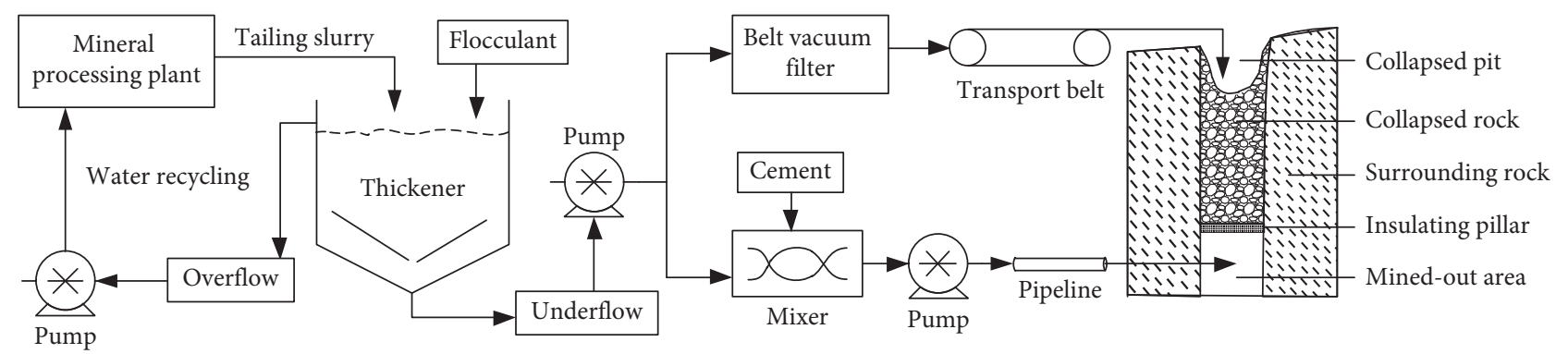

Figure 15: Technological process of tailings backfilling.

mine to solve the surface subsidence problem, i.e., after the recovery of residual ore body above $905 \mathrm{~m}$, the subsidence areas in ground surface should be backfilled in time with the noncemented tailings, and an insulating pillar with thickness of $20 \mathrm{~m}$ should be reserved beneath the collapsed waste rock layer; when excavating the ore body beneath the insulating pillar, the cut-and-fill mining method is recommended to replace the current sublevel caving mining method, and the cemented tailings can be used as the filing material for the mined-out areas. In order to efficiently utilize the tailings and realize no tailings discharging to the tailings reservoir, the noncemented backfilling of surface collapse pit and the cemented filling of underground mined-out area can be carried out at the same time. This backfill scheme has been approved and accepted by the Hongling lead-zinc mine.

The technological process of tailings backfilling for the collapse pit and mined-out area is shown in Figure 15. After the mineral processing, the tailing slurry with the concentration of $10 \% \sim 20 \%$ is transported from the mineral processing plant to the thickener. In the thickener, a part of water is separated from the tailing slurry, and the flocculant is added to the thickener to accelerate the precipitation process. After the precipitation of tailing slurry, the waste water (overflow) is transported from the thickener back to the mineral processing plant through the water pumping station, realizing the recycling of water resource. In addition, the tailings with the concentration of $45 \%$ 55\% (underflow) can be obtained through the thickener, which is the primary material for the noncemented backfilling of surface collapse pit and the cemented filling of underground mined-out area. On the one hand, a part of underflow is transported to the belt vacuum filter to further reduce the water content of tailings. The filter cakes with the concentration of $80 \% \sim 85 \%$ can be obtained through the belt vacuum filter and are transported through the belt to the surface collapse pit as the backfill material. On the other hand, the rest of underflow is transported to mixer and mixed with the cement, and finally the cemented tailings are transported through the pipeline to the underground mined-out areas as the filling material.

\section{Conclusions}

Based on the geological conditions of Hongling lead-zinc mine, a two-dimensional numerical model was established by PFC2D to study the mechanism of ground surface subsidence and movement law of backfill material due to underground mining, and the following conclusions can be drawn:

(1) When the sublevel caving mining method is adopted, the marble will collapse firstly and lead to the formation of collapse pit in ground surface. With the continued excavation of ore body, two tensile stress concentration zones appear in ground surface of both sides of the collapse pit, and a compressive stress concentration zone appears in the bottom of the collapse pit. The release of horizontal stresses results in the toppling failure in hanging wall and then leading to the occurrence of a larger collapse pit in ground surface. After the toppling failure of hanging wall, a part of mined-out area is filled by the collapsed waste rock, and the collapsed rock can to some extent provide support force for the surrounding rock.

(2) When the mined-out area above $905 \mathrm{~m}$ is backfilled by the noncemented tailings and an insulating pillar is reserved at the bottom of collapse pit, if the sublevel caving mining method is still adopted, the insulating pillar will crush and the stability of collapsed waste rock and backfill material cannot be maintained, and a large collapse pit will reoccur in ground surface; if the cut-and-fill method is adopted after the backfill of mined-out area, the backfill material and the surrounding rock can remain stable, and the collapse pit will not appear in ground surface. Moreover, when the cut-and-fill mining method is adopted for underground mining, the insulating pillar can provide large support force for the surrounding rock and maintain the stability of collapsed waste rock and backfill material.

(3) After excavation of mining level $705 \mathrm{~m}$, the vertical displacement contour of the model exhibits a "V" shape, and the surrounding rock closer to the excavation zone and ground surface exhibits larger vertical displacement. When the ore body is excavated by the sublevel caving mining method without backfilling the mined-out area, a large collapse pit with a width of $214 \mathrm{~m}$ and a depth of $75 \mathrm{~m}$ appears in ground surface. When the mined-out area above $905 \mathrm{~m}$ is backfilled by the noncemented tailings, if the sublevel caving method is still adopted, the 
backfill material can reduce the depth of collapse pit to some extent but cannot prevent the occurrence of collapse pit; if the mining method is changed to the cut-and-fill method, then the surface subsidence can be controlled and no obvious subsidence pit appears in ground surface. The cut-and-fill mining method can efficiently control the surface subsidence and prevent the occurrence of collapse pit in ground surface.

\section{Data Availability}

The data used to support the findings of this study are available from the corresponding author upon request.

\section{Conflicts of Interest}

The authors declare that they have no conflicts of interest.

\section{Acknowledgments}

The authors would like to thank the National Natural Science Foundation of China (grant nos. 41630642 and 51674288) for providing financial support.

\section{References}

[1] Y.-Y. Yang, Y.-S. Xu, S.-L. Shen, Y. Yuan, and Z.-Y. Yin, "Mining-induced geo-hazards with environmental protection measures in Yunnan, China: an overview," Bulletin of Engineering Geology and the Environment, vol. 74, no. 1, pp. 141-150, 2015.

[2] X. Cui, Y. Gao, and D. Yuan, "Sudden surface collapse disasters caused by shallow partial mining in Datong coalfield, China," Natural Hazards, vol. 74, no. 2, pp. 911-929, 2014.

[3] S. Wang, X. Li, and S. Wang, "Separation and fracturing in overlying strata disturbed by longwall mining in a mineral deposit seam," Engineering Geology, vol. 226, no. 30, pp. 257-266, 2017.

[4] C. Yi, J. Sjöberg, and D. Johansson, "Numerical modelling for blast-induced fragmentation in sublevel caving mines," Tunnelling and Underground Space Technology, vol. 68, pp. 167-173, 2017.

[5] F. G. Bell, T. R. Stacey, and D. D. Genske, "Mining subsidence and its effect on the environment: some differing examples," Environmental Geology, vol. 40, no. 1-2, pp. 135-152, 2000.

[6] M. Svartsjaern, "A prognosis methodology for underground infrastructure damage in sublevel cave mining," Rock Mechanics and Rock Engineering, vol. 52, no. 1, pp. 247-263, 2019.

[7] E. Can, Ş. Kuşcu, and M. E. Kartal, "Effects of mining subsidence on masonry buildings in Zonguldak hard coal region in Turkey," Environmental Earth Sciences, vol. 66, no. 8, pp. 2503-2518, 2012.

[8] E. Hoek, "Progressive caving induced by mining an inclined ore body," Transactions of the Institution of Mining \& Metallurgy, vol. 83, no. 815, pp. 33-39, 1974.

[9] E. T. Brown and G. A. Ferguson, "Prediction of progressive hanging-wall caving, Gath's mine, Rhodesia," Transactions of the Institution of Mining and Metallurgy Section A, vol. 88, pp. A92-A105, 1979.

[10] W. Ren, C. Guo, Z. Peng, and Y. Wang, "Model experimental research on deformation and subsidence characteristics of ground and wall rock due to mining under thick overlying terrane," International Journal of Rock Mechanics and Mining Sciences, vol. 47, no. 4, pp. 614-624, 2010.

[11] H. Y. Dai, X. G. Lian, J. Y. Liu et al., "Model study of deformation induced by fully mechanized caving below a thick loess layer," International Journal of Rock Mechanics and Mining Sciences, vol. 47, no. 6, pp. 1027-1033, 2010.

[12] B. Ghabraie, G. Ren, X. Zhang, and J. Smith, "Physical modelling of subsidence from sequential extraction of partially overlapping longwall panels and study of substrata movement characteristics," International Journal of Coal Geology, vol. 140, pp. 71-83, 2015.

[13] T. Villegas, E. Nordlund, and C. Dahnér-Lindqvist, "Hangingwall surface subsidence at the Kiirunavaara mine, Sweden," Engineering Geology, vol. 121, no. 1-2, pp. 18-27, 2011.

[14] H. Zhao, F. Ma, Y. Zhang, and J. Guo, "Monitoring and mechanisms of ground deformation and ground fissures induced by cut-and-fill mining in the Jinchuan mine 2, China," Environmental Earth Sciences, vol. 68, no. 7, pp. 1903-1911, 2013.

[15] X. G. Song, C. X. Chen, K. Z. Xia, K. Y. Yang, S. Chen, and X. M. Liu, "Analysis of the surface deformation characteristics and strata movement mechanism in the main shaft area of Chengchao Iron Mine," Environmental Earth Sciences, vol. 77, no. 9, p. 335, 2018.

[16] G. Cheng, T. Ma, C. Tang, H. Liu, and S. Wang, “A zoning model for coal mining - induced strata movement based on microseismic monitoring," International Journal of Rock Mechanics and Mining Sciences, vol. 94, pp. 123-138, 2017.

[17] K. Xia, C. Chen, Y. Deng et al., "In situ monitoring and analysis of the mining-induced deep ground movement in a metal mine," International Journal of Rock Mechanics and Mining Sciences, vol. 109, pp. 32-51, 2018.

[18] N. Xu, P. H. S. W. Kulatilake, H. Tian, X. Wu, Y. Nan, and T. Wei, "Surface subsidence prediction for the WUTONG mine using a 3-D finite difference method," Computers and Geotechnics, vol. 48, no. 3, pp. 134-145, 2013.

[19] Q. Wu and P. H. S. W. Kulatilake, "Application of equivalent continuum and discontinuum stress analyses in three-dimensions to investigate stability of a rock tunnel in a dam site in China," Computers and Geotechnics, vol. 46, pp. 48-68, 2012.

[20] L. C. Li, C. A. Tang, X. D. Zhao, and M. Cai, "Block cavinginduced strata movement and associated surface subsidence: a numerical study based on a demonstration model," Bulletin of Engineering Geology and the Environment, vol. 73, no. 4, pp. 1165-1182, 2014.

[21] X. Deng, J. Zhang, T. Kang, and X. Han, "Strata behavior in extra-thick coal seam mining with upward slicing backfilling technology," International Journal of Mining Science and Technology, vol. 26, no. 4, pp. 587-592, 2016.

[22] T. N. Do, J. H. Wu, and H. M. Lin, "Investigation of sloped surface subsidence during inclined seam extraction in a jointed rock mass using discontinuous deformation analysis," International Journal of Geomechanics, vol. 17, no. 8, article 04017021, 2017.

[23] B. Tan, F. Ren, Y. Ning, R. He, and Q. Zhu, "A new mining scheme for hanging-wall ore-body during the transition from open pit to underground mining: a numerical study," Advances in Civil Engineering, vol. 2018, Article ID 1465672, 17 pages, 2018.

[24] M. Svartsjaern, D. Saiang, E. Nordlund, and A. Eitzenberger, "Conceptual numerical modeling of large-scale footwall behavior at the Kiirunavaara mine, and implications for 
deformation monitoring," Rock Mechanics and Rock Engineering, vol. 49, no. 3, pp. 943-960, 2016.

[25] S. F. Wang and X. B. Li, "Dynamic distribution of longwall mining-induced voids in overlying strata of a coalbed," International Journal of Geomechanics, vol. 17, no. 6, article 04016124, 2017.

[26] A. Vyazmensky, D. Elmo, and D. Stead, "Role of rock mass fabric and faulting in the development of block caving induced surface subsidence," Rock Mechanics and Rock Engineering, vol. 43, no. 5, pp. 533-556, 2010.

[27] A. Vyazmensky, D. Stead, D. Elmo, and A. Moss, "Numerical analysis of block caving-induced instability in large open pit slopes: a finite element/discrete element approach," Rock Mechanics and Rock Engineering, vol. 43, no. 1, pp. 21-39, 2010.

[28] D. Stead, E. Eberhardt, and J. S. Coggan, "Developments in the characterization of complex rock slope deformation and failure using numerical modelling techniques," Engineering Geology, vol. 83, no. 1-3, pp. 217-235, 2006.

[29] T. Villegas and E. Nordlund, "Numerical simulation of the hangingwall subsidence using PFC2D," in Proceedings of the 5th International Conference and Exhibition on Mass Mining, Luleå, Sweden, June 2008.

[30] T. F. V. Barba and E. Nordlund, "Numerical analyses of the hangingwall failure due to sublevel caving: Study case," International Journal of Mining and Mineral Engineering, vol. 4, no. 3, pp. 201-223, 2013.

[31] M. Svartsjaern and D. Saiang, "Discrete element modelling of footwall rock mass damage induced by sub-level caving at the Kiirunavaara Mine," Minerals, vol. 7, no. 7, p. 109, 2017.

[32] L. Zhao and W. Jin-an, "Accident investigation of mine subsidence with application of particle flow code," Procedia Engineering, vol. 26, pp. 1698-1704, 2011.

[33] X. Li, J. Du, L. Gao et al., "Immobilization of phosphogypsum for cemented paste backfill and its environmental effect," Journal of Cleaner Production, vol. 156, pp. 137-146, 2017.

[34] B.-Y. Hu, X.-M. Wang, S. Li, J.-W. Zhao, and N. M. Eugénie, "Stability Analysis and Confidence Level Evaluation of Backfill Mining under High and Steep Rock Slopes," Advances in Civil Engineering, vol. 2018, Article ID 1465672, 17 pages, 2018.

[35] W. Sun, H. Wang, and K. Hou, "Control of waste rock-tailings paste backfill for active mining subsidence areas," Journal of Cleaner Production, vol. 171, pp. 567-579, 2018.

[36] F. Wang, Q. Ma, G. Li, C. Wu, and G. Guo, "Overlying Strata Movement Laws Induced by Longwall Mining of Deep Buried Coal Seam with Superhigh-Water Material Backfilling Technology," Advances in Civil Engineering, vol. 2018, Article ID 3029796, 12 pages, 2018.

[37] X. D. Zhao, "Stability analysis of insulating pillar of excavation of Chambishi copper mine in depth," Chinese Journal of Rock Mechanics \& Engineering, vol. 29, pp. 2616-2622, 2010.

[38] S. J. Chen, D. W. Yin, F. W. Cao, Y. Liu, and K. Q. Ren, “An overview of integrated surface subsidence-reducing technology in mining areas of China," Natural Hazards, vol. 81, no. 2, pp. 1129-1145, 2016.

[39] X. B. Li, D. Y. Li, Z. X. Liu, G. Y. Zhao, and W. H. Wang, "Determination of the minimum thickness of crown pillar for safe exploitation of a subsea gold mine based on numerical modelling," International Journal of Rock Mechanics and Mining Sciences, vol. 57, no. 1, pp. 42-56, 2013.

[40] E. Hoek, C. Carranza-Torres, and B. Corkum, "Hoek-Brown failure criterion-2002 Edition," in Proceedings of the Fifth
North American Rock Mechanics Symposium, pp. 267-273, Toronto, Ontario, Canada, 2002.

[41] D. O. Potyondy and P. A. Cundall, "A bonded-particle model for rock," International Journal of Rock Mechanics and Mining Sciences, vol. 41, no. 8, pp. 1329-1364, 2004.

[42] C. J. Li and X. B. Li, "Influence of wavelength-to-tunnel-diameter ratio on dynamic response of underground tunnels subjected to blasting loads," International Journal of Rock Mechanics and Mining Sciences, vol. 112, pp. 323-338, 2018.

[43] X. B. Li, C. J. Li, W. Z. Cao, and M. Tao, "Dynamic stress concentration and energy evolution of deep-buried tunnels under blasting loads," International Journal of Rock Mechanics and Mining Sciences, vol. 104, pp. 131-146, 2018.

[44] L. J. Lorig, C. Darcel, B. Damjanac, M. Pierce, and D. Billaux, "Application of discrete fracture networks in mining and civil geomechanics," Mining Technology, vol. 124, no. 4, pp. 239254, 2015.

[45] Y. B. Zhang, F. Y. Ren, T. H. Yang, S. Y. Wang, W. F. Zhang, and M. X. Yu, "An improved rock mass characterization method using a quantified geological strength index and synthetic rock mass model," Rock Mechanics \& Rock Engineering, vol. 51, no. 2, pp. 3521-3536, 2018.

[46] R. Rafiee, M. Ataei, R. Khalookakaie, S. E. Jalali, F. Sereshki, and M. Noroozi, "Numerical modeling of influence parameters in cavabililty of rock mass in block caving mines," International Journal of Rock Mechanics and Mining Sciences, vol. 105, pp. 22-27, 2018. 


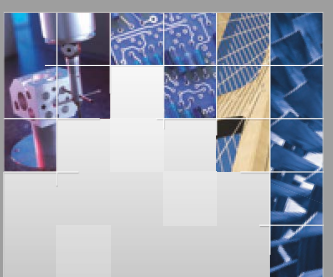

\section{Enfincering}
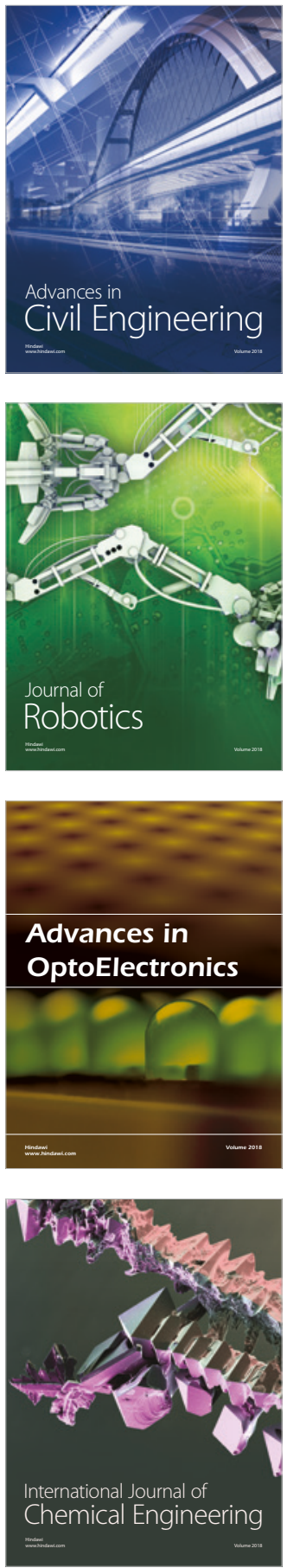

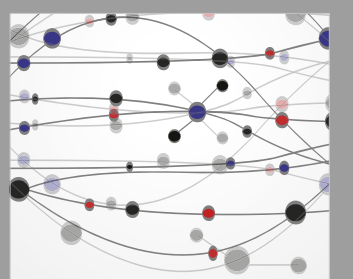

\section{Rotating \\ Machinery}

The Scientific World Journal

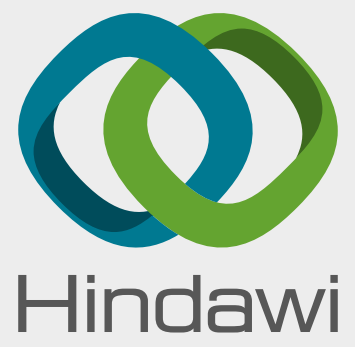

Submit your manuscripts at

www.hindawi.com
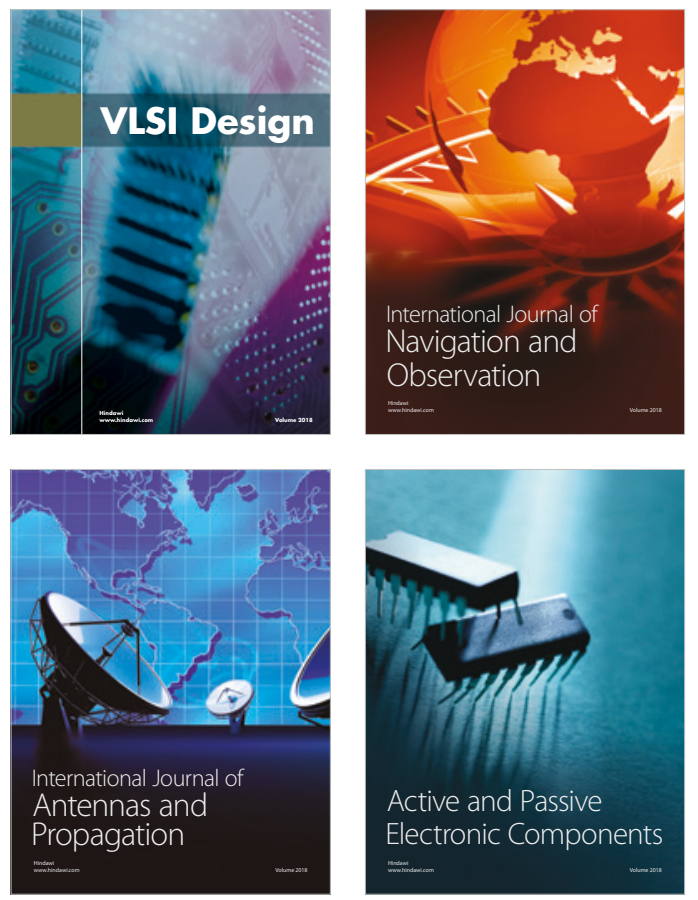
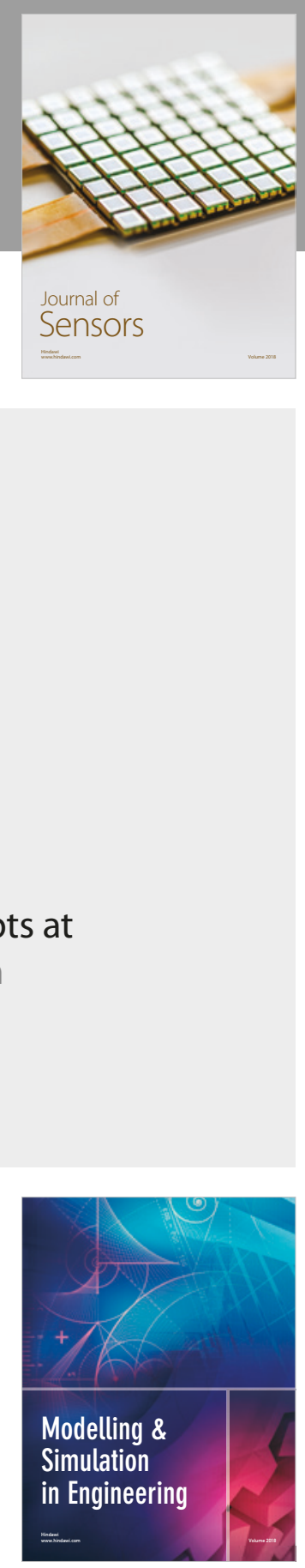

\section{Advances \\ Multimedia}
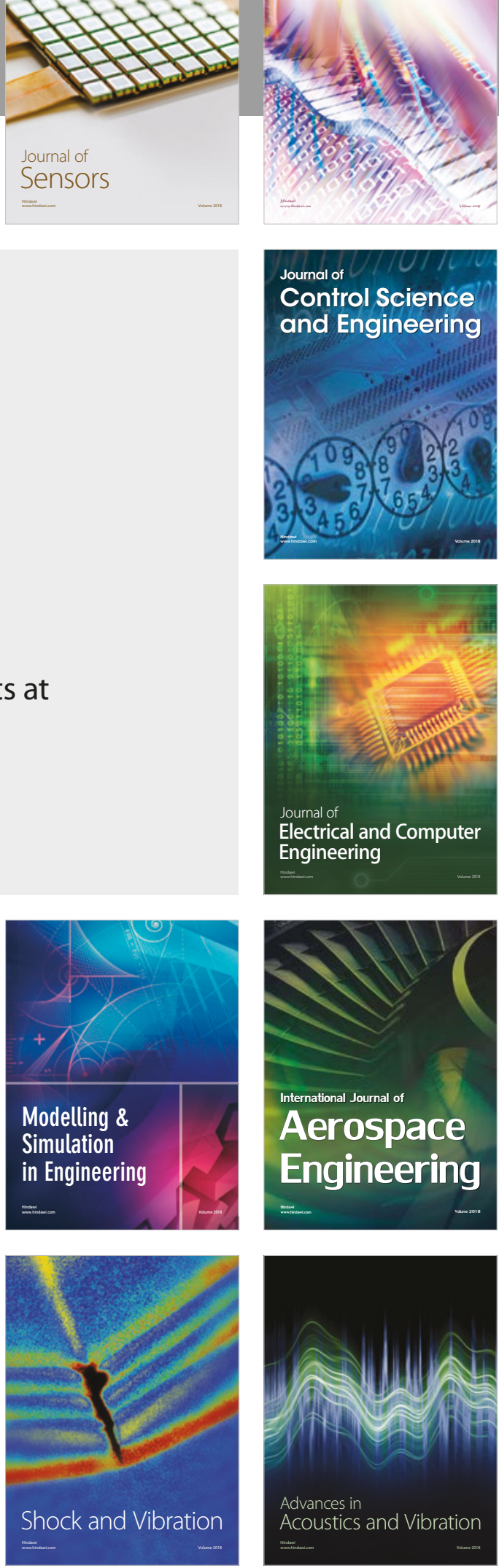